\title{
ULCINJANI U KREDITNOJ TRGOVINI DUBROVNIKA U DRUGOJ POLOVICI XIV. STOLJEĆA
}

\author{
Marijan PREMOVIĆ \\ Filozofski fakultet Univerziteta Crne Gore \\ Nikšić, Crna Gora
}

\author{
UDK: 336.77(497.5 Dubrovnik)“13“" \\ DOI: https://dx.doi.org/10.21857/yk3jwhrxp9 \\ Izvorni znanstveni rad \\ Prihvaćeno: 25. siječnja 2019.
}

U radu se prikazuje kreditna trgovina Ulcinjana u Dubrovniku u drugoj polovici XIV. stoljeća. Istraživanje je zasnovano na analizi građe iz Državnog arhiva u Dubrovniku (ser. 26 Diversa Notariae, ser. 35 Diversa Cancellariae i ser. 36 Debita Notariae) i relevantnoj povijesnoj literaturi. Jedan dio članka odnosi se na političke odnose između Ulcinja i Dubrovnika. Obrađeni kronološki, ponuđeni su podatci i činjenice o političkim zbivanjima između ove dvije komune. Osim političkih, analiziran je i utjecaj zdravstvenih prilika na razvoj i opseg kreditne trgovine. Drugi dio rada odnosi se na kreditno poslovanje Ulcinjana u Gradu sv. Vlaha. Tragom spomenute arhivske građe, prezentirali smo trgovačku karijeru i aktivnost pojedinih trgovaca. Njihove osnovne trgovačke krugove činile su njihove obitelji, rodbina, prijatelji i poznanici u obje komune. Materijalna dobit potaknula ih je na suradnju. Predstavljen je način uzimanja kredita iz godine u godinu, navedene su značajnije trgovačke obitelji, manje poznati ulcinjski pojedinci u kreditnoj trgovini i poslovanje trgovačkih društava, kojom su robom najčešće trgovali, kreditna jamstva (jamci i zalog), prokuratori, rokovi vraćanja kredita i kamatne stope. Navedena su najvažnija imena dužnika i kreditora te kolike kredite uzimaju. Analiziran je opseg i vrijednost trgovine kreditima te prikazan promet i rekonstrukcija gospodarske povijesti Ulcinja, što je uslijed neraspoloživosti građe matičnog arhiva od posebne važnosti.

Ključne riječi: Ulcinjani, Dubrovnik, kreditna trgovina, trgovačka društva, XIV. stoljeće.

\section{UVOD}

Na temelju neobjavljenih vrela iz Dubrovnika sadržanih u serijama Debita Notariae (Notarske zadužnice), Diversa Cancellariae (Različiti spisi kancelarije) i Diversa Notariae (Različiti notarski spisi) ${ }^{1}$ te historiografskih radova i relevantne literature ${ }^{2}$ prikazat ćemo kreditnu zaduženost isključivo Ulcinjana za svaku

1 Građa koja nas zanima prvenstveno je u obliku raznih trgovačkih ugovora, ugovora o jamstvima i poslovnim udruživanjima. Hrvatska - Državni arhiv u Dubrovniku, Dubrovnik (dalje: HR-DAD), Diversa Notariae (Div. Not.), ser. 26, sv. 7 - 10; Diversa Cancellariae (Div. Canc.), ser. 35, sv. 17 - 33; Debita Notariae (dalje: Deb. Not.), ser. 36, sv. 3 - 11.

2 Najvažnija djela koja smo konzultirali pri pisanju rada: Ignacij VoJe, Kreditna trgovina u srednjovjekovnom Dubrovniku, Sarajevo, 1976.; Marica MALović-ĐukIć, Privredne veze Ulcinja i Dubrovnika krajem XIV i početkom XV veka, Istoriski časopis, sv. 40 - 41, Beograd, 1993. - 1994., 57 - 70; Dušanka Dinıć-KnežEvić, Migracije stanovništva iz južnoslovenskih zemalja u Dubrovnik 
pojedinu godinu tijekom druge polovice XIV. stoljeća. Najvažnije vrelo za istraživanje te problematike je serija Debita Notariae koja se čuva u Državnom arhivu u Dubrovniku. Ta serija počinje 1282. godinom i ima izuzetan značaj za proučavanje zaduženosti trgovaca kreditima. ${ }^{3}$ Ugovori o zaduživanju imaju prilično ujednačenu formu bilježenja koja najčešće sadrži verbalnu invokaciju, datum, informacije o dužnicima, mjesto odakle dolaze, rjeđe imena jamaca, zatim ime kreditora, sumu zaduživanja u novcu, rok otplate i prateće mjere kojima kreditori osiguravaju vraćanje kredita. ${ }^{4}$ Opseg i kretanje vrijednosti kreditne trgovine prikazani su na temelju bogate arhivske građe iz druge polovice XIV. stoljeća. U istraživanju je obrađena građa iz svezaka III. - XII., koji obuhvaćaju vremenski raspon od 1352. do 1396. godine. Analiza nije potpuna jer za pojedine godine knjige zaduženja nisu sačuvane u cijelosti. Veći su prekidi između godina 1339. - 1352., 1370. - 1378., 1382. - 1389. i 1396. - 1400. ${ }^{5}$

Da bi smo dobili cjelovitiju sliku djelovanja ulcinjskih poduzetnika u Dubrovniku, konzultirali smo serije Diversa Cancellariae i Diversa Notariae. Serija Diversa Cancellariae obuhvaća sveske XVII. - XXXIII. u razdoblju 1351. - 1352., 1354. - 1356., 1362. - 1372., 1375. - 1376., 1381. - 1383. i 1385. - 1402. godine. Sadrži dokumente koji se odnose na sudske poslove (tužbe, ročišta, iskazi svjedoka, presude i ostalo), oglase o prodaji nekretnina itd. ${ }^{6} \mathrm{U}$ zapisima kancelarije nalazimo važne podatke koji nam objašnjavaju pojedine probleme vezane uz kreditnu trgovinu i djelovanje trgovačkih društava. Kancelari su u svoje knjige bilježili zaključke sudskih institucija koji su se odnosili na sporove između partnera u kreditnim poslovima. ${ }^{7}$ Fond Diversa Notariae obuhvaća

tokom srednjeg veka, Novi Sad, 1995.; Marica Malović-Đukić, Delatnost Stefana Marinova u drugoj polovini 14. veka,, Istoriski časopis, sv. 44, Beograd, 1998., 105 - 110; Ignacij Voje, Poslovna uspešnost trgovcev v srednjeveškem Dubrovniku, Ljubljana, 2003.; Božidar ŠEKUlARAC, Crna Gora u doba Balšića, Cetinje, 2011.; Marica Malović-Đukić, Porodica Kimo-Klimo iz Ulcinja u srednjem veku (14-15. vek), Spomenica akademika Sime Ćirkovića (ur. Srđan Rudić), Beograd, 2011., 404 406; Nenad VeKa RIĆ, Vlastela grada Dubrovnika 7. Genealogije $(A-L)$, Zagreb - Dubrovnik, 2016.; Nenad Vekarić, Vlastela grada Dubrovnika 8. Genealogije ( $M-Z)$, Zagreb - Dubrovnik, 2017.

3 Esad KuRTović, Izvori za historiju srednjovjekovne Bosne I/1 (Ispisi iz knjiga zaduženja Državnog arhiva u Dubrovniku 1365-1521). Sarajevo, 2017., IX - X.

4 I. VoJE, Kreditna trgovina, 70; E. KuRTović, Izvori, IX.

5 HR-DAD, Deb. Not., ser. 36, sv. 3 - 11; O notarima u drugoj polovici XIV. stoljeća vidjeti: Constantin JiReČEK, Die mittelalterliche Kanzlei der Ragusaner. II. Die slaviscehe Kanzlei, Archiv für slavische Philologie, 26, Berlin, 1904., 189 - 192; Jorjo TADIĆ, Pisma $i$ uputstva dubrovačke republike, knj. 1, Beograd, 1935., XXV - XXXVII; I. VOJE, Kreditna trgovina, 23 26; I. Voje, Poslovna uspešnost, 28 - 31.

6 HR-DAD, Div. Canc., ser. 35, sv. 17 - 33.

7 I. Voje, Kreditna trgovina, 82 - 84; Esad Kurtović, Arhivska grada za historiju srednjovjekovne Bosne (Ispisi iz knjiga kancelarije Državnog arbiva u Dubrovniku 1341-1526), kj. 1, Sarajevo, 2019., XI. - XII. 
sveske III. - XI. u vremenskom razdoblju 1352. - 1358., 1362. - 1379. i 1387. 1391. godine. ${ }^{8} \mathrm{U}$ Diversa su upisane sljedeće isprave: zadužnice, mirazi, kupnje i prodaje, oglasi i pozivi o konfiskaciji dužnikove imovine, objave o zapljeni dužnikove imovine ili založenih predmeta itd. Zabilježene su sankcije prema dužnicima i pozivi da se u određenom roku moraju javiti na sud. ${ }^{9}$ Arhivske serije koje smo koristili preciziraju status i akcije pojedinaca i zbog toga su bitne; ne odnose se na cijelu zajednicu, što je uglavnom obilježje odluka Vijeća umoljenih (Senata) i Malog vijeća.

O kreditnoj trgovini Ulcinjana u Gradu sv. Vlaha pisano je malo u povijesnoj znanosti. Poneki podatak o tome nalazi se u djelima općeg karaktera, ${ }^{10}$ a u pojedinim studijama koje obrađuju gospodarsku djelatnost Ulcinjana ne nalaze se podatci o toj temi. ${ }^{11} \mathrm{O}$ kreditnoj trgovini u Dubrovniku postoji više studija. ${ }^{12}$ Iznimno važna istraživanja o kreditnoj trgovini Dubrovnika u srednjem vijeku napravio je slovenski povjesničar Ignjacij Voje, jedan od boljih poznavatelja dubrovačkog arhiva. ${ }^{13}$ Prikazujući ogromnu građu iz notarijata, na nekoliko mjesta prikazao je kreditnu trgovinu Ulcinjana, ali ne navodi ni dužnike ni vjerovnike poimenice. ${ }^{14}$ Marica Malović-Đukić nastavila je istraživanja u tom smjeru prikazujući kreditno poslovanje samo nekoliko istaknutih trgovaca iz 1366. i od 1389. do 1396. godine. ${ }^{15}$ Dušanka Dinić-Knežević u studiji o migracijama navela je nekoliko važnijih trgovca i obrtnika koji su se tijekom

HR-DAD, Div. Not., ser. 36, sv. 3 - 11.

I. Voje, Kreditna trgovina, $80-82$.

10 B. Šekularac, Crna Gora, 106.

11 Maksut Dž. Hadžibrahimović, Pomorstvo i trgovina srednjovjekovnog Ulcinja, Hrvatskocrnogorski dodiri / crnogorsko-hrvatski dodiri: identitet povijesne i kulturne baštine Crnogorskog primorja, Zbornik radova (ur. Lovorka Čoralić), Zagreb, 2009., 249 - 269; Branislav MARović, Ekonomska istorija Crne Gore (Od najstarijih vremena do kraja XX vijeka), Podgorica, 2018., 40 - 51.

12 Na ovom mjestu donosimo samo izbor: Desanka KovačEvić, Trgovina u srednjovjekovnoj Bosni, Sarajevo, 1961.; Bogumil HrabaK, Poslovni ljudi Polimlja (1350 - 1700), Simpozijum Seoski dani Sretena Vukosavljevića, sv. III, Prijepolje, 1976., 235 - 269; Branislav Milutinović, Zaduženja prizrenskih trgovaca kod Dubrovčana 1355 - 1369, Vjetar i Arkivit të Kosovës - Godišnjak Arhiva Kosova, sv. XIV. - XV., Priština, 1982. (1978. - 1979.), 45 - 60; Pavo Žıvкović, Ekonomskosocijalne promjene u bosanskom društvu u XIV i XV stoljeću, Tuzla, 1986.; Esad Kurtović, Neki pokazatelji o poslovanju Vuka Petkovića, trgovca iz Pljevalja, Almanah, sv. 29/30, Podgorica, 2005. 235 - 241; Esad Kurtović, Zaduživanja Radoja Dubjevića, trgovca iz Foče, Bosna franciscana, sv. 14, br. 25, Sarajevo, 2006., 181 - 190; Esad KuRTović, Hrebeljanovići, Balićievići i ostali fočanski trgovci u periodu 1469 - 1524. godine, Zbornik radova u čast akademiku Desanki Kovačević Kojić (ur. Rajko Kuzmanović, Dragoljub Mirjanić i Đuro Tošić), Banja Luka, 2015., 327 - 372.

13 I. VoJe, Kreditna trgovina; I. VoJe, Poslovna uspešnost.

14 Obimnu građu iz serije Debita Notariae sustavno je iskoristio do 1364., prikazao je 1368., 1380., 1382., 1390. i 1395. godinu. I. VoJE, Kreditna trgovina, 216, 225, 227.

15 M. Malović-Đukić, Privredne veze, 60 - 69; M. Malović-Đukić, Delatnost Stefana Marinova, 105 - 110; M. Malović-Đukić, Porodica Kimo, 405 - 406. 
srednjeg vijeka iz Ulcinja preselili u Dubrovnik. ${ }^{16}$ Ulcinjsko-dubrovačke kreditne veze tijekom srednjeg vijeka problematika je koja unatoč opsežnosti i nezaobilaznosti u ukupnom razmatranju gospodarskih odnosa i prožimanja još uvijek nema posebnu studiju.

Izabrali smo ovo razdoblje da bi prikazali trgovačke odnose između ulcinjske i dubrovačke komune nakon epidemije kuge u Gradu 1348., promjene dubrovačkog političkog statusa nakon Zadarskog mira 1358. i dolaska Ulcinja pod vlast zetske obitelji Balšića 1368. godine. Na temelju dubrovačkih vrela analizirat ćemo trgovačku karijeru i aktivnosti trgovaca u kreditnoj trgovini, kada je ta suradnja bila najveća, a kada joj je opseg smanjen, o čemu to ovisi u pojedinim periodima, postoji li udruživanje pojedinaca i stvaranje mreže trgovaca, odnosno tko su ti ljudi koji surađuju i po kojim se linijama povezuju i sl. Do odgovarajućih zaključaka doći ćemo analitičkim postupkom, uspoređujući dostupne podatke i sa statističkog aspekta, $s$ ciljem izvođenja konačne sinteze.

Veliki dio trgovine u srednjovjekovnom Dubrovniku bio je zasnovan na kreditima. Ugovori su zaključivani pred notarom. Cijeli kreditni ugovor morao je biti upisan u notarsku knjigu. Isprava imala je javnu vjeru i služila je pred sudom kao neoboriv dokaz. U slučaju da se isprava zagubi, stranka se uvijek mogla pozvati na notarski registar u kojem je bio traženi zapis, a koji je bio u vlasništvu dubrovačke komune. Notarska isprava činila je okosnicu poslovnog života dalmatinskih komuna. ${ }^{17}$ Gradski statut ulcinjske komune i arhivska građa, koji svjedoče o kreditnim poslovima, nisu sačuvani. ${ }^{18}$ Oni su osmanskim osvajanjem 1571. propali. ${ }^{19}$ Ipak, zahvaljujući detaljnom uvidu u dubrovačka vrela, imamo mogućnost steći jasniju predodžbu o gospodarstvu ulcinjske komune.

Ulcinj se nalazi na krajnjem južnom dijelu Jadranskog mora. Podignut je na stjenovitoj uzvisini nad morem, pozicioniran u ravnici između planinskih ogranaka Rumije i Prokletija. Ulcinjska komuna obuhvaćala je teritorij (distrikt)

16 D. Dinić-Knežević, Migracije stanovništva, 135 - 136, 211 - 213.

17 O tome vidjeti više u: Branka Grbavac, Srednjovjekovni notarski formulari i njihovi sastavljači, Javni bilježnik, sv. 34, Zagreb, 2011., 32 - 38; Branka GrBAVAC, Iz prošlosti javnog notarijata - od notarskog bastardela do izdane isprave, Javni bilježnik, sv. 36, Zagreb, 2012., 61 - 68.

18 Ulcinjski notari u vrelima se bilježe 1261., a statut grada prvi se put spominje 1366. (svakako je nastao ranije). Miloš Antonović, Grad i župa u Zetskom primorju i severnoj Albaniji u XIV i XV veku, Beograd, 2003., 120; Savo MAR ković, Notarijati medievalnih komuna crnogorskog primorja (odrazi antičkog nasljeđa, autonomnosti urbaniteta i humanističkog univerzalizma), Acta Histriae, sv. 18, br. 4, Koper, 2010., 836. Usporedi: Tomislav RAU KAR, Srednjovjekovne ekonomije i hrvatska društva, Zagreb, 2003., 14 - 15; Branka GrbavAC, Notari kao posrednici između Italije i Dalmacije studije, službe, seobe između dvije obale Jadrana, Acta Histriae, sv. 16, br. 4, Koper, 2008., 506 - 515.

19 Dušanka Dinić-KNEžEvić, Zetski primorski gradovi u svetlu dubrovačkih izvora, Srednjovjekovna istorija Crne Gore kao polje istraživanja (ur. Branislav Kovačević), Podgorica, 1999., 131. 
ulcinjskog i Anamalskog polja, planinski masiv Možure i Zogajsko blato. ${ }^{20}$ Dalmatinska srednjovjekovna komuna bila je otvorena prema svom zaleđu. ${ }^{21}$ Dubrovnik je, zahvaljujući svom izvanrednom geografskom položaju na jugu Jadrana i snažnom gospodarskom razvoju, privlačio mnoge trgovce iz ulcinjske komune. ${ }^{22}$ Trgovački promet između ove dvije komune odvijao se kopnenim i morskim putom. Kopnenim putom via de Zenta polazile su trgovačke karavane iz Dubrovnika preko Novog, prema Risnu starom rimskom cestom, zatim u Kotor i Budvu. Cesta je išla obalom i karavane su tako dolazile do Ulcinja, odakle su nastavljale za Skadar. Osim ovog kopnenog puta bilo je i vodenih putova. Brodovi natovareni robom plovili su iz grada Jadranskim morem do Ulcinja. ${ }^{23}$

Veliki značaj za gospodarski život Ulcinjana imala je blizina rijeke Bojane. Njezin vodeni tok povezivao je Jadransko more sa Skadarskim jezerom, rijekom Drimom, sa Skadrom i Drivastom. U nju su ulazili dubrovački brodovi s Jadrana, kao što su fuste i manji brodovi, do samostana sv. Srđa i Bakha na lijevoj obali Bojane, gdje se nalazilo pristanište portus Sancti Sergii. ${ }^{24}$ Na području od Neretve do Bojane trgovina solju bila je ograničena samo na četiri mjesta: Drijeva, Dubrovnik, Kotor i Sv. Srđ i Bakh. Oko samostana na Bojani bila su skladišta (magazini) soli i trgovačke kuće. Dubrovački trgovci dovozili su i prodavali sol iz Valone. Trgovina solju u XIV. stoljeću bila je vrlo razgranata. S ovog trga roba je preuzimana i transportirana karavanama u unutrašnjost Balkana. U unutrašnjosti sve do tuzlanskog bazena nije bilo prirodnih nalazišta soli. Dubrovčani su korištenjem rijeke Bojane i Trga sv. Srđa kapitalizirali svoju trgovinsku dobit. ${ }^{25}$

20 Enciklopedija Jugoslavije, sv. VIII., Zagreb, 1971. (dalje: Enciklopedija Jugoslavije VIII.), 416; Đurđe Boš Ković, Pavle Mijović, Mirko KovačEvić, Ulcinj I., Beograd, 1981, 5; M. Antonović, Grad i župa, 45; Siniša Mıšıć i suradnici, Leksikon gradova i trgova srednjovekovnih srpskih zemalja: prema pisanim izvorima, Beograd, 2010., $304-307$.

21 Usporedi: Tomislav RaUkAR, Komunalna društva u Dalmaciji u XV. i u polovini XVI. stoljeća, Historijski zbornik, god. 25, br. 1, Zagreb, 1982., 43 - 47, 99 - 117.

22 I. Voje, Kreditna trgovina, 216, 227; M. Malović-Đukić, Privredne veze, 57 - 70; D. DinićKNEŽEvić, Migracije stanovništva, 211 - 213; M. Malović-Đu KIĆ, Delatnost Stefana Marinova, 105 - 110; M. Malović-Đukić, Porodica Kimo, 405 - 406.

23 Konstantin JireČEK, Trgovački putevi i rudnici Srbije i Bosne u srednjem veku, Zbornik Konstantina Jirečeka I, Beograd, 1959., 276 - 279; Gavro ŠKrivanić, Putevi u srednjovekovnoj Zeti, Glasnik Srpskog geografskog društva, sv. 51, br. 1, Beograd, 1971., 75 - 77, 83.

24 Momčilo Spremić, Sveti Srđ pod mletačkom vlašću: (1396 - 1479), Zbornik Filozofskog fakulteta, sv. 7 - 1, Beograd, 1963., 295 - 296; Spremić se zaustavio na pregledu gospodarske djelatnosti u mjestu Sv. Srđ tijekom razdoblja mletačke uprave, ali ne govori dovoljno o pitanjima kojima se ovdje bavimo i zbog toga odlazimo korak dalje u znanstvenom istraživanju. Usporedi: Siniša MIŠIĆ, Istorijska geografija srpskih zemalja: od 6. do polovine 16. veka, Beograd, 2014., 115.

25 Milena Gecić, Dubrovačka trgovina solju u XIV veku, Zbornik Filozofskog fakulteta, sv. 3, Beograd, 1955., 95, 100, 112, 123, 149; M. Spremić, Sveti Srd, 295 - 297; Bogumil HrabaK, Promet soli u Skadru i Bojani u XIII, XIV i XV, u: Arbanaške studije III, ur. Bogumil Hrabak, Beograd, 2005., 95 - 98. 
Kuga iz 1348. godine izazvala je promjene u svim područjima života u Gradu sv. Vlaha. Pojavila se najvjerojatnije tijekom zadnjih dana prethodne godine. $\mathrm{Na}$ osnovi analize oporuka utvrđeno je da je epidemija najžešće harala u ožujku i travnju, a tijekom svibnja intenzitet opada. Već krajem lipnja epidemija je prestala. Crna smrt privremeno je zaustavila gospodarski život Grada. Vrela ne bilježe sklapanje trgovačkih društava, a tek su u lipnju zabilježeni novi trgovački poslovi. ${ }^{26}$ Demografski gubitak teško je precizno odrediti, a na temelju oporuka (sačuvano ih je preko 300 ) vidi se da je smrtnost bila velika. ${ }^{27} \mathrm{U}$ gradu se osjećao nedostatak zanatlija pa je zato Veliko vijeće 30. svibnja 1348. pozvalo strane obrtnike da dođu u grad i nasele se uz znatne povlastice: godišnje premije od 5 perpera i oslobođenje od plaćanja svih poreza (izuzev uvozne carine) ako se obvežu da će ostati najmanje pet godina. ${ }^{28}$ Pozivu se odazvao veći broj stanovnika s Apeninskog poluotoka i dalmatinskih komuna s istočnog Jadrana. ${ }^{29}$ Ova mjera dubrovačkih vlasti ubrzo je urodila plodom i trgovina se početkom pedesetih godina XIV. stoljeća počela vraćati u svoj raniji ritam. ${ }^{30}$ Mnogi preživjeli potomci trgovaca nakon kuge naslijedili su značajne količine novca koje su uložili $u$ trgovinu, u uvoz ili izvoz robe. ${ }^{31} \mathrm{Za}$ gospodarski uspon presudnu je ulogu imao pristup balkanskom zaleđu, osobito bogatstvu rudnih sirovina u Srbiji i Bosni. ${ }^{32}$ U drugom valu, tijekom 1352. i 1353. godine, u Grad dolaze i posluju mnogi trgovci, među njima i Ulcinjani (de Dulcinio, Dulcigno). ${ }^{33}$

26 Iscrpan prikaz tijeka epidemije kuge 1348. vidjeti u: Gordan Ravančıć, Direktni učinci Crne smrti u Dubrovniku 1348. godine, Historični seminar, br. 6, ur. Katarina Kerber, Katarina Šter, Ljubljana, 2008., 57 - 73; Gordan Ravančić, Vrijeme umiranja - Crna smrt u Dubrovniku 1348.1349., Zagreb, 2010., 71 - 87; Gordan Ravančić, Crna smrt 1348. godine u Dubrovniku - godina krize i solidarnosti?, Sačuvaj nas Bože rata, kuge, gladi i velike trešnje (ur. Gordan Ravančić), Zagreb, 2018., $11-27$.

27 O utjecaju kuge na demografiju Dubrovnika 1348. vidjeti u: G. RAVANČIć, Vrijeme umiranja, 114 - 121; Nenad VeKarić, Vlastela grada Dubrovnika 1. Korijeni, struktura i razvoj dubrovačkog plemstva, Zagreb - Dubrovnik, 2012., 226 - 227.

28 Monumenta Ragusina: libri reformationum. T. II, A. 1347.-1352. 1356.-1360., Zagrabiae, 1882., 25 - 26, 29 - 30; Ivan Božıć, Ekonomski i društveni razvitak Dubrovnika u XIV - XV veku, Istorijski glasnik, sv. 1, Beograd, 1949., 30; Sima Ćır ković, Dubrovnik i zaleđe u srednjem veku, Rabotnici, vojnici, duhovnici: društva srednjovekovnog Balkana, Beograd, 1997., 53 - 54; Dušanka DinićKnežEviĆ, Migracije stanovništva iz bližeg zaleđa u Dubrovnik u XIV veku, Jugoslovenski istorijski časopis, sv. 1 - 2, Beograd, 1974., 26 - 27; D. Dinić-KneŽEvić, Migracije stanovništva, 59; Zrinka PeŠorda-VARDiĆ, U predvorju vlasti. Dubrovački antunini u kasnom srednjem vijeku, Zagreb Dubrovnik, 2012., 36.

29 Z. Pešorda-VARDić, U predvorju vlasti, 36.

30 Dušanka Dinić, Uticaj kuge od 1348. na privredu Dubrovnika, Godišnjak Filozofskog fakulteta, sv. 5, Novi Sad, 1960., $31-32$.

31 O tome vidjeti u: I. VoJe, Kreditna trgovina, $210-211$.

32 Z. PEŠORDA-VARDIĆ, U predvorju vlasti, 37.

33 I. VoJe, Kreditna trgovina, 211, 216. 
U potrazi za poslom u Grad u drugoj polovici XIV. stoljeća dolazi i manji broj Ulcinjana da bi radili kao sluge ili šegrti. Na Dubrovnik su gledali kao na obećani grad u potrazi za boljim životom. Pružao im je mogućnost da prežive i nešto zarade. Dubrovačkim obrtnicima i trgovcima trebali su šegrti, a bogatim vlastelinskim i građanskim obiteljima kućna posluga. Vrela bilježe njihov boravak u gradu, koji se odnosi na ulazak u službu služenja ${ }^{34}$ ili dolazak na studij obrta. ${ }^{35}$

\section{POLITIČKA ZBIVANJA NA JUŽNOM JADRANU I UTJECAJ NA KREDITNU TRGOVINU}

Na razvoj kreditne trgovine i razvitak gospodarskih odnosa između Ulcinja i Dubrovnika važan su utjecaj imale političke prilike. Te dvije komune na južnom Jadranu razvijale su se pod različitim vrhovnim gospodarima u drugoj polovici XIV. stoljeća. Poslije smrti srpskog cara Dušana (20. prosinca 1355.) Ulcinj je bio pod vlašću njegove udovice, carice Jelene, ${ }^{36}$ koja je priznavala vrhovnu vlast svog sina cara Uroša (1355. - 1371.). ${ }^{37}$ Dubrovnik je do 1358. bio pod vrhovnom vlašću Venecije, a tada je Višegradskim ugovorom potvrđen kao dio Ugarskohrvatskog Kraljevstva. ${ }^{38}$ Komuna je ojačala svoj položaj pa osim kopnene dolazi i do razvitka pomorske trgovine. ${ }^{39}$

Nesređene prilike u Srbiji poslije Dušanove smrti odrazile su se na trgovinu. Početkom 1361. Dubrovčani su osjetili da srpski car Uroš nije imao stvarnu vlast nad komunom Ulcinj..$^{40}$ Suverenu vlast imala je njegova majka carica

34 Div. Not., sv. 7, f. 26v, (20. 8. i 27. 8. 1352.); sv. 7, f. 117v, (8. 11. 1356.); sv. 9, f. 18'v, (22. 6. 1377.); Div. Canc., sv. 27, f. 22v, (22.9. 1387.).

35 Div. Not., sv. 9, f. $141^{\prime}$ v, (5.11.1375.); sv. 10, f. 1'v, (prije 22.10. 1387.).

36 Mletačka se vlada pismom obratila Jeleni kao gospodarici Ulcinja 14. svibnja 1357. Šime LJUBIĆ, Listine o odnošajih izmedju Južnoga Slavenstva i Mletačke Republike., knj. III. od godine 1347 do 1358, U Zagrebu, 1872., 343 - 344.

37 Rade Min ALjČIć, Kraj Srpskog carstva, Beograd, 2001., 28 - 32.

38 Dušanka Dinić-KnežEvić, Dubrovnik i Ugarska u srednjem veku, Novi Sad, 1986., 17 - 20; Zdenka JANEKović-RöMER, Priznanje krune svetog Stjepana - izazov dubrovačke diplomacije, Diplomacija Dubrovačke Republike, Zbornik Diplomatske akademije 3 (ur. Svjetlan Berković), Zagreb, 1998., 296 - 299; Zdenka JANEKoviĆ-RöMER, Višegradski ugovor: temelj Dubrovačke Republike, Zagreb, 2003., 10 - 48, 64 - 68, 80 - 85, 90 - 116; Robin HARris, Povijest Dubrovnika, Zagreb, 2006., 59 - 62; Lovro KunčEvić, Mit o Dubrovniku. Diskursi o identitetu renesansnoga grada, Zagreb - Dubrovnik, 2015., 84, 93, 116; Darko BEKIĆ, Povijest hrvatske diplomacije, svezak prvi do 1918., Zagreb, 2016., 131.

39 D. Dinić-Knežević, Dubrovnik i Ugarska, 214 - 215; Franjo Šanjek, Branka Grbavac i suradnici, Leksikon hrvatskoga srednjovjekovlja, Zagreb, 2017., 192.

40 Dušanka Dinıć-KnežEvić, Tkanine u privredi srednjovekovnog Dubrovnika, Beograd, 1982., 55. 
Jelena koja se očitovala kroz vođenje samostalne vanjske politike. ${ }^{41}$ Trgovce su početkom 1361. opljačkali ljudi majke cara Uroša bez njezina znanja. ${ }^{42}$ Ubrzo dolazi do otvorenog rata između Dubrovnika i Srbije, koji je vodio knez Vojislav Vojinović (početak XIV. stoljeća - 25. 10. 1363.). ${ }^{43} \mathrm{Njemu}$ su se pridružili i Kotorani. Sredinom 1361. carevim podanicima bilo je zabranjeno dolaziti u grad i trgovati. ${ }^{44}$ Ulcinjska komuna bila je oslobođena od ovih dubrovačkih mjera jer je bila saveznik Dubrovnika. ${ }^{45}$

U jesen 1362. godine obitelj Balšić nastojala je zauzeti Ulcinj. ${ }^{46}$ Držali su komunu pod opsadom i tražili od Dubrovčana da ju ne opskrbljuju. Gradske vlasti pokušale su ih izmiriti, ali ništa nije ostalo zabilježeno o eventualnom uspjehu ili neuspjehu misije. ${ }^{47}$ Dubrovčani su se umiješali u taj sukob jer su ratna zbivanja ugrožavala slobodnu i sigurnu trgovinu i bili su zainteresirani da je zaštitite. Zato su gradske vlasti imale običaj sudjelovati kao arbitri u rješavanju sporova u svojoj neposrednoj blizini. ${ }^{48}$ Zbog napada Balšića na ulcinjsku komunu tijekom 1362. vidimo da je došlo do prekida kreditne trgovačke aktivnosti Ulcinjana u gradu. Carica Jelena bila je potisnuta iz Ulcinja, a od 1364. godine komuna se našla pod vlašću arbanaškog gospodara Karla Topija. ${ }^{49}$ U Ulcinju je 18. listopada 1364. dubrovačkom trgovcu Grubi Junijevu Mençi (oko 1325. - 1371.) oduzeta sol..$^{50}$ Lovro Lamprin Mençe (oko

41 Sime Ljubić, Listine III, 343 - 344; Monumenta Ragusina: libri reformationum III, A. 1359. 1364., Zagrabiae, 1895., (dalje: Monumenta Ragusina III), 22, 67, 202; Dušanka Dinić-KNEŽEvić, Položaj žena u Dubrovniku u XIII i XIV veku, Beograd, 1974., 23; Đ. Bošković, P. Mijović, M. KovačEvić, Ulcinj I., 11.

42 Monumenta Ragusina III, 75.

43 O knezu Vojislavu Vojinoviću: Gordana Tomović, Vojinovići, Spomenica akademika Sime Ćirkovića (ur. Srđan Rudić), Beograd, 2011., 358 - 360.

44 Monumenta Ragusina III, 92.

45 D. Dinić-Knežević, Tkanine, 55; R. Minaljčić, Kraj Srpskog, 60.

46 Vidjeti: Božidar ŠE KULARAC, Balšići - od oblasnih gospodara do moćne dinastije, Balšići (Zbornik radova sa skupa Balšići, Ivanova Korita, 21. - 22. rujna 2011., ur. Čedomir Drašković), Cetinje Podgorica, 2012., $31-36$.

47 Istorija Crne Gore II/2, Titograd, 1970., 18.

48 U studenom 1388. godine dubrovački poslanik Mihoč Šimunov Resti (oko 1347. - 1431.) bio je medijator u sporu bosanskog kralja Tvrtka I. i Đurađa II. Stracimirovića Balšića. Mihailo J. Dinić, Odluke veća Dubrovačke republike II, Beograd, 1964., 446; O Mihoču Restiju vidjeti više u: Nenad VeKarić, Vlastela grada Dubrovnika 6. Odabrane biografije (Pi - Z), Zagreb - Dubrovnik, 2015., 125 - 126; O dubrovačkim misijama i ceremonijalu vidjeti opširno u: Valentina Zovko, Diplomatske ovlasti kao preduvjet uspješnosti provedenih misija glede dubrovačkih teritorijalnih akvizicija, Miscellanea Hadriatica et Mediterranea, vol. 1, Zadar, 2012., 59 - 76; Valentina Zovko, Diplomatski ceremonijal - Važan oblik komunikacije u pregovorima oko proširenja dubrovačkih granica, Radovi za povijesne znanosti HAZU u Zadru, sv. 55, 2013., 18 - 40; Valentina Zovko, Metode i tehnike komunikacije između vlasti i poslanika u pregovorima oko proširenja dubrovačkih granica, Anali Zavoda za povijesne znanosti HAZU u Dubrovniku, sv. 52/1, 2014., 21 - 49.

49 Enciklopedija leksikografskog zavoda, sv. VII., Zagreb, 1964., 456; Enciklopedija Jugoslavije VIII., 355. 
1320. - oko 1384.) poslan na pregovore s Karlom Topijom o ovom slučaju. ${ }^{51}$ Kao protumjera, sljedećeg mjeseca zaplijenjena je imovina Ulcinjana u Dubrovniku. ${ }^{52} \mathrm{U}$ prosincu iste godine Dubrovčanima je iznova oduzeta sol..$^{53}$

Zbog borbi oko Ulcinja između arbanaškog velikaša sa skadarskog područja Topije i nove zetske dinastije Balšića bila je poremećena trgovina između Ulcinja i Dubrovnika. ${ }^{54}$ Od druge polovice studenog do kraja prosinca 1364. zbog ovih događanja trgovci iz Ulcinja ne dolaze po kredite u Dubrovnik. Iduće godine dolazi do normalizacije trgovačkih odnosa. Objema stranama bilo je u interesu da se veze ne prekidaju, Dubrovčanima zbog sigurnosti u ulcinjskoj komuni i na Trgu sv. Srđa, a Ulcinjanima zbog dubrovačkog tržišta, mogućnosti zapošljavanja i nalaženja utočišta. Dubrovačka vlada u ljeto 1366. izdaje uputstvo poslaniku Matu Nikiforovu Bodaçi (oko 1327. - oko 1370.) za diplomatsku misiju kod Karla Topije. ${ }^{55}$ Dubrovački poklisar odigrao je važnu ulogu kao medijator, uspio je pomiriti Đurđa I. s arbanaškim gospodarom. ${ }^{56}$ Balšići su osvojili Ulcinj u proljeće 1368. godine. Od tada pa do 1405 . Ulcinj se nalazi pod vlašću ove zetske obitelji. ${ }^{57}$ Ulcinj je u doba njihove vladavine imao veliki značaj, u njemu se nalazila prijestolnica Đurađa II. Stracimirovića Balšića (1385. - 1403.).58 Kada je učvršćena vlast Balšića u Ulcinju, nastupio je novi trgovački zamah s Gradom sv. Vlaha. Dok je bila na vlasti, obitelj Balšić bila je u dobrim odnosima s Dubrovčanima. Postoje indicije da su samo 1372. godine iznevjerili prijateljstvo s Dubrovnikom. ${ }^{59}$ Prijateljstvo se zasnivalo na činjenici da su braća Balšići

50 Josephüs Gelcich, Monumenta Ragusina: libri reformationum IV, A. 1364. - 1396., Zagrabiae, 1896., 32; Vidjeti: Nenad VEKARIĆ, Vlastela grada Dubrovnika 3. Vlasteoski rodovi (M - Z), Zagreb - Dubrovnik, 2012., 49.

51 J. Gelcich, Monumenta Ragusina IV, 32; N. Vexarić, Vlastela grada 3, 46.

52 J. Gelcich, Monumenta Ragusina IV, 36; Irmgard Manken, Dubrovački patricijat u XIV veku I, Beograd, 1960., 341.

53 J. GelCiCH, Monumenta Ragusina IV, 38.

54 Istorija Crne Gore II/2, 19 - 21; Žarko ŠćEPANović, Kratka istorija Crne Gore: od najstarijih vremena do 1796. godine, Podgorica, 2002., 61; Josip Jelčıć, Zeta i dinastija Balšića: dokumentovane istorijske studije, preveo i priredio Radoslav Rotković, Podgorica, 2010., 64 - 65; B. ŠEKULARAC, Crna Gora, 37 - 38.

55 J. Gelcich, Monumenta Ragusina IV, 49; Nenad Ve KARIć, Vlastela grada Dubrovnika 2. Vlasteoski rodovi $(A-L)$, Zagreb - Dubrovnik, 2012., 83.

56 Istorija Crne Gore II/2, $20-21$.

57 Đ. Bošković, P. Mijović, M. Kovačević, Ulcinj I, 11.

58 Istorija Crne Gore II/2, 50.

59 Dubrovčani su 16. svibnja 1372. ugarsko-hrvatskom kralju uputili informaciju da Venecija pokušava od Đurđa I. Balšića i Nikole Altomanovića dobiti vojsku za rat protiv Dubrovnika, Ludovika I. i Padove. Zetskom gospodaru obećano je da će dobiti Drač i Kotor, a Altomanoviću Ston i Pelješac. Nemamo podatke u vrelima je li došlo do realizacije navedenog saveza. HR-DAD, Lettere e commissioni. Lettere di Levante (dalje: Lettere di Levante), ser. 27.1, sv. 2, f. 81v, (16. 5. 1372.); Vinko Foretić, Povijest Dubrovnika do 1808. Deo 1, Od osnutka do 1526., Zagreb, 1980., 155. 
u srpnju 1361. postali počasni dubrovački građani. ${ }^{60}$ Gradske su vlasti ovim diplomatskim činom izrazile prijateljstvo u svoje ime i u ime čitave zajednice. Od svojih počasnih građana vlada je očekivala podršku i pomoć. Svaki neprijateljski čin značio je izdaju povjerenja i prijateljstva. ${ }^{61}$ Spomenute indicije o mogućem sukobu nisu realizirane jer o tome nema spomena u vrelima i nije bilo nikakvih negativnih posljedica na kasnije odnose.

Zetski gospodari Balšići uvidjeli su da trgovina s Dubrovnikom ima izuzetan značaj. Zbog toga su potakli gospodarsku suradnju izdavanjem povelja Gradu sv. Vlaha. Povelje sadrže odredbe kojima se jamči sigurnost dubrovačkih građana i nastojanje zetskih gospodara da se ostvari jača gospodarska suradnja. ${ }^{62}$ Braća Stracimir, Đurađ I. i Balša II. poveljom od 17. siječnja 1368. ukinuli su carinu na Danju. ${ }^{63}$ Đurađ I. Balšić poveljom od 30. studenog 1373. obećao je Dubrovčanima da neće uvoditi carine koje nisu postojale u vrijeme cara Dušana. ${ }^{64}$ Poveljom od 30. svibnja (nije upisano koje godine, smatra se da je nastala u razdoblju 1374. 1376.) Đurad I. Balšić jamči Dubrovčanima da neće ometati trgovački promet između Grada i Zete. ${ }^{65}$ Balša II. Balšić u povelji od 20. studenog 1379. propisao je da Dubrovčani na Danju i Krivoj Rijeci plaćaju carinu kao u vrijeme Đurđa I. ${ }^{66} \mathrm{U}$ povelji Balše II. od 24. travnja 1385. određeno je da Dubrovčani ne plaćaju carinu i prelaze preko rijeke, a koje odredbe nisu bile zakonite u vrijeme cara Dušana i Đurđa I. ${ }^{67}$ Iako je prethodnim poveljama već bila osigurana pravna sigurnost dubrovačkih trgovaca, Đurađ II. Stracimirović Balšić je 27. siječnja 1386. poveljom ponovo propisao da njegovi podređeni ne smiju na svoju ruku nametati nezakonite namete $\mathrm{i}$ da se šteta, ako je trgovci pretrpe, mora nadoknaditi. Ukinuo je sve trgove soli uvedene poslije smrti cara Dušana. ${ }^{68}$ Poveljama iz 1385.

60 Lettere di Levante, sv. 2, f. 28'v (29. 07. 1361.); Istorija Crne Gore II/2, 12 - 13.

61 Jovanka Mijušković, Dodjeljivanje dubrovačkog građanstva u srednjem veku, Glas $S A N U$, sv. 9, Beograd, 1961., $104-106$.

62 V. Foretić, Povijest Dubrovnika 1, 154 - 156, 181; Božidar Šexularac, Dukljansko - zetske povelje, Titograd, 1987., 159 - 173; Srđan Rudić, Balšići i Dubrovnik - prilog poznavanju pravnih odnosa, Istorijski časopis, sv. 62, Beograd, 2013., 35 - 45.

63 Srđan Rudić, Povelja Balšića Dubrovčanima, Stari srpski arhiv, sv. 9, Beograd, 2010., 93 - 98.

64 Srđan Rudić, Povelja Đurđa I Balšića Dubrovniku, Stari srpski arhiv, sv. 8, Beograd, $2009 ., 101$ 110 .

65 Srđan Rudić, Povelja Đurđa I Balšića Dubrovčanima, Stari srpski arbiv, sv. 8, Beograd, 2009., 111 $-117$.

66 Srđan Rudić, Povelja Balše II kojom potvrđuje Dubrovčanima privilegije dobijene od brata mu Đurđa, Stari srpski arhiv, sv. 10, Beograd, 2011., 103 - 107.

67 Srđan Rudić, Povelja duke dračkog Balše II Dubrovčanima, Stari srpski arhiv, sv. 11, Beograd, 2012., 101 - 106.

68 Marijan Premović, Povelja Đurđa Stracimirovića Balšića Dubrovčanima od 27. januara 1386. godine, Stari srpski arhiv, sv. 15, Beograd, 2016., 143 - 155. 
i 1386. godine uređeno je pitanje dubrovačkih lađa koje bi doživjele brodolom na teritoriju pod kontrolom Balšića. $S$ dubrovačke lađe nastradale na moru ili rijeci nitko nije smio ništa uzeti. ${ }^{69}$ Opetovanom potvrdom tih povelja osnaživano je prijateljstvo i darivane su trgovačke slobode koje su dubrovačkim trgovcima osiguravale dobre uvjete za rad. Pod uvjetima podrazumijevamo slobodu kretanja, zaštitu trgovine i nepovredivost imovine. Tako je trgovina između Dubrovnika i Ulcinja dobila je novi poticaj zahvaljujući interesima Balšića kao novih gospodara Ulcinja.

U dubrovačkom susjedstvu Bosna je jamčila slobodnu trgovinu dubrovačkim trgovcima. Kralj Tvrtko I. (1353. - 1391.) izdao je 1378. povelju Dubrovniku. Bosanski vladar omogućuje slobodnu trgovinu stanovnicima Grada u svom kraljevstvu, kraljevi službenici i podanici nisu ih smjeli uznemiravati ni pljačkati. Svaka šteta morala je biti nadoknađena. ${ }^{70}$ Usporedbom ovih odredbi sodredbama u poveljama Balšića možemo istaknuti da ne postoje bitnije razlike. Dubrovčani su štitili svoju trgovačku dobit, a Zeta i Bosna imale su gospodarsku korist.

\section{UTJECAJ ZDRAVSTVENIH PRILIKA}

Na razvitak i opseg kreditne trgovine utjecala je i epidemija kuge. ${ }^{71}$ Postojala je velika mogućnost da Dubrovnik i Ulcinj kao priobalni gradovi budu izloženi zarazi koja je preko trgovine mogla doći na njihovo područje. Nakon Crne smrti 1348. zaraza se ponovo vraćala na dubrovačko područje. Do novog pomora došlo je već 1361. godine, a zaraza je trajala oko godinu dana. Epidemija je ponovo harala tijekom 1363. godine. Prema intenzitetu nije bila puno blaža od one iz 1348. godine. Kuga je ponovo harala 1371., 1372., 1373. i 1374. godine. Ove epidemije izazvale su manju smrtnost $u$ gradu. ${ }^{72}$ Nemamo podatke u knjizi zadužnica o intenzitetu uzimanja kredita za navedene godine. Vjerojatno je tada bila smanjena kreditna djelatnost Ulcinjana u gradu. Zbog straha od novih epidemija dubrovačke Srednjovekovno pravo u Srba u ogledalu istorijskih izvora (ur. Sima Ćirković, Kosta Čavoški), Beograd, 2009., 217 - 232; Neven IsAilović, Trgovinski odnosi između Bosne i Dubrovnika u srednjem veku: diplomatički osvrt, Zbornik radova u čast akademiku Desanki Kovačević Kojić (ur. Rajko Kuzmanović, Dragoljub Mirjanić i Đuro Tošić), Banja Luka, 2015., 241; Dženan Dautović, Enes Dedić, Povelja kralja Tvrtka I Kotromanića Dubrovniku (Žrnovnice, 10. april 1378 Trstivnica, 17. juni 1378), Godišnjak, sv. 45, Sarajevo, 2016., 229 - 234.

71 D. Dinić-Knežević, Uticaj kuge, 11 - 32; Gordan Ravančić, Crna smrt, 11 - 34.

72 Risto Jeremić, Jorjo TADIĆ, Prilozi za istoriju zdravstvene kulture starog Dubrovnika I, Beograd, 1938., 68 - 69; G. RAVANČıć, Vrijeme umiranja, 71 - 87; G. RAVANČıć, Crna smrt, 11 - 34. 
su vlasti 27. srpnja 1377. donijele zakon o zabrani ulaska u Grad onima koji dolaze iz zaraženih krajeva. Ova mjera nije zaustavljala promet ljudi i robe, ali je donekle omogućila kontrolu i sprječavanje bolesti da dođe do Grada. ${ }^{73}$

Grad je zbog kuge nekoliko puta zabranjivao dolazak trgovcima iz Ulcinja. ${ }^{74}$ Malo vijeće 1. travnja 1391. donosi odluku da se zbog kuge ne dozvoli vlasnicima brodova i njihovoj posadi, kao ni nikom drugom, odlazak u mjesta Budva usque Dulcinium propter pestem que dicitur esse in illis locis et partibus. ${ }^{75}$ Isto tako, zabranjuje se pristup svima onima koji bi s područja od Budve do Ulcinja htjeli doći u Dubrovnik. Prekršitelji su mogli biti kažnjeni novčanom kaznom do 100 dukata. ${ }^{76}$ Početkom svibnja 1391. zaraza je ipak stigla u Dubrovnik s budvanskoulcinjskog područja. Veliko vijeće objaviloje odluku s uputama kako treba upravljati Gradom ako preživi samo manji broj vlastele. U drugoj polovini prosinca ta je odredba poništena jer je opasnost od zaraze prestala. U siječnju 1392. donesena je odluka o formiranju četveročlane protukužne službe koja je imala dužnost raditi na suzbijanju zaraze. Prekršiteljima su izricali novčane kazne prema vlastitom nahođenju ili su ih kažnjavali tjelesnim kaznama. ${ }^{77}$ Te je godine u zaleđu ponovo izbila kuga. Grad je 7. lipnja 1392. zabranio svojim trgovcima da odlaze u Ulcinj et ad alia loca ubi sit pestis. ${ }^{78}$ Činovnici za suzbijanje kuge izdaju naredbu da nitko od Dubrovčana ne smije ploviti put Splita ili Ulcinja, u bilo koje mjesto gdje hara kuga, pod kaznom spaljivanja barke i novčane globe. Ako prekršitelj ne bi imao novca, treba mu odsjeći uho i prognati ga van dubrovačkog teritorija. Osobama koje prijave kršenje zabrane zajamčena je anonimnost i polovica naplaćene kazne. ${ }^{79}$ Nažalost, u vrelima nemamo podatke kakve su mjere poduzimane u Ulcinju.

Malo vijeće je 11. lipnja 1392. odlučilo osobama iz Ulcinja zabraniti boravak na dubrovačkom području, od Molunta prema zapadu, uključujući i Mljet. ${ }^{80}$ Zaraza je došla s mora, preko trgovačkih brodova. Ta opaka bolest obustavljala je kreditnu i trgovačku djelatnost, stradalo je stanovništvo, a neizbježne su bile promjene na svim područjima života Ulcinja. ${ }^{81}$ Unatoč teškoćama izazvanima nesređenim političkim prilikama i povremenim zarazama, trgovina i promet uvijek su nalazili svoj put.

73 Z. Blažina-Tomić, Kacamorti i kuga, 81 - 82; N. VeKARIĆ, Vlastela grada 1, 235.

74 Nella Lonza, Zdravko ŠundricA, Odluke dubrovačkih vijeća 1390 - 1392, Zagreb - Dubrovnik, 2005., (dalje: N. LoNZA, Z. ŠUndRICA, ODV 1390 - 1392), 153, 182, 233 - 234.

75 N. LONZA, Z. ŠUNDRICA, ODV 1390 - 1392, 153.

76 N. LonZA, Z. ŠUndRICA, ODV 1390 - 1392, 153; Z. BlažInA-Tomić, Kacamorti i kuga, 87.

77 Z. BlažınA-Tomić, Kacamorti i kuga, 87.

78 N. LonZA, Z. ŠundRICA, ODV 1390 - 1392, 233 - 234.

79 Div. Can., sv. 30, f. 112v, (7.6. 1392.).

80 N. LONZA, Z. ŠUNDRICA, ODV 1390 - 1392, 183.

81 Z. BlažINA-Tomić, Kacamorti i kuga, 17. 


\section{KREDITI}

Najznačajnija „financijska destinacija“ na istočnoj obali Jadrana bio je Dubrovnik, vrlo privlačan trgovcima iz Zete, Srbije i Bosne. U XIV. stoljeću bio je „središte velikih komercijalnih transakcija i novčanih kredita“. Da bi došli u posjed dobara, većini trgovaca bio je potreban kredit, koji su redovito uzimali na određeni vremenski rok. Dubrovačka komuna 1275. izdaje zakon da se svi kreditni poslovi koji premašuju svotu od 10 perpera moraju sklapati pismeno. ${ }^{82}$ U notarijatu prvi Ulcinjani kao dužnici upisani su 1282. godine. ${ }^{83}$ Nedostatak novčanih sredstava omogućavao je davanje robe na odgođeno plaćanje, na kredit, uz određenu proviziju. U najvećem broju slučajeva u kreditnim transakcijama poslovalo se robom, a u manjem broju novcem. I. Voje smatra da dugovi u ugovorima označavaju vrijednost prodane i neisplaćene robe, a vraćanje duga liferaciju druge robe samom kreditoru. ${ }^{84} \mathrm{U}$ ugovorima je teško odvojiti robu od novca jer je većinom vrijednosti robe izražavana u novcu. U gradovima Rijeci i Trstu koristila su se dva koncepta zadužnica: novac i robni kredit. ${ }^{85}$ Vrijednost kreditirane trgovačke robe obračunava se u dubrovačkim dinarima (grošima), perperima i mletačkim dukatima. U drugoj polovici XIV. stoljeća vrijednost dubrovačkog dinara iznosila je 30 folara. Jedan perper iznosio je 12 dinara, a dva perpera bila su ekvivalentna jednom mletačkom dukatu. Odnos mletačkog dukata prema dubrovačkom novcu iznosio je 24 dinara. Osamdesetih godina XIV. stoljeća taj je odnos promijenjen pa je jedan dukat vrijedio 2,5 perpera ili 30 dinara ${ }^{86}$ Ulcinjanin Marko Lukin Clime zadužio se 29. rujna 1380. kod Marina Mihova Bone (oko 1340. - 1417.) za 137 dukata, u obračunu 30 dinara za jedan dukat. ${ }^{87}$ Godine 1382 . vrijednost dukata u odnosu na dinar uglavnom

82 Statut grada Dubrovnika: sastavljen godine 1272., priredili i preveli Ante Šoljić, Zdravko Šundrica i Ivo Veselić, Dubrovnik, 2002., (dalje: Statut grada Dubrovnika), 426 - 427; Ignacij Voje, Knjige zadolžnic: posebna notarska serija Dubrovniškega arhiva: univ. profesorju dr. Gregorju Čremošniku ob 10-letnici njegove smrti, Zgodovinski časopis, sv. XXII, br. 3 - 4, Ljubljana, 1968., 210 - 211.

83 Josip Lučić, Pomorsko-trgovačke veze Dubrovnika s gradovima zetskog i dračkog primorja u XIII stoljeću, Pomorski zbornik, knj. 7, Zadar, 1969., 839.

84 I. VoJe, Kreditna trgovina, 92.

85 I. VoJe, Kreditna trgovina, $91-104$.

86 O tome: Milan REŠETAR, Dubrovačka numizmatika I (bistorički) dio, Beograd, 1924., 50 - 59, 472 - 485; Milan ReŠEtar, Dubrovačka numizmatika, II (Opisni) dio, Beograd, 1925., 48 - 111; I. MANKEN, Dubrovački patricijat I, 106.

87 Ego quidem Marcus quondam Luce de Chimo de Duicinio confiteor, quod super me et super omnia bona mea usque ad tres menses proxime venturos me obligo dare et solvere ser Luce de Bona ypperperos quingentos grossorum. Et sit de presenti viagio. Et si ultra dictum terminum etc. Renunciando etc. Ser Marinus Iunii de Mençe iudex et. Ser Symon de Bona testis. Deb. Not., sv. 9, f. 31v, (29. 9. 1380.); Vidjeti: Nenad VeKarić, Vlastela grada Dubrovnika 4. Odabrane biografije $(A-D)$, Zagreb Dubrovnik, 2013., 
se kreće oko 32, a vrlo rijetko 30 dinara. Do kraja XIV. stoljeća tečaj je obično bio 30 dinara za jedan dukat. ${ }^{88}$

Poznati dubrovački trgovac, diplomat i ekonomist Benedikt Kotruljević u svom znamenitom djelu Libro del arte dela mercatura iz 1458. godine ističe da je prodaja kredita nužna zbog nedostatka novca i stimuliranja trgovanje. On navodi da kada se roba daje na određeni vremenski rok, kreditor mora paziti na šest stvari: stvar koju daje, osobi kojoj daje, rok koji ugovara, količinu, dobit i način plaćanja. ${ }^{89} \mathrm{Na}$ temelju zadužnica koje su notari upisivali iz dana u dan, iz godine u godinu, možemo pratiti razvitak kreditnog poslovanja. Ugovori sadrže imena dva svjedoka, gradskog sudca i trgovca, koji su jamčili poštivanje ugovornih odredbi. Gradskih je sudaca u Dubrovniku bilo pet, birali su se u Velikom vijeću u rujnu svake godine. Pri potpisivanju isprava često su se mijenjali, navodimo neke: Andrija Pankracijev Benessa (oko 1300. - 1380.), Junije (Junko) Marinov Sorgo (oko 1345. - 1401.), Marin (Maroje) Junijev Mençe (oko 1317. - 1380.), Jakov Điva Gondula (oko 1340. - 1415.) itd. ${ }^{90}$ Drugi svjedok bio je najčešće viđeniji dubrovački trgovac iz redova vlastele i pučana koji su se bavili kreditnim poslovima. Među njima nalazimo: Nikolu (Nikšu) Marinova Mençu (oko 1325. - 1402.), Leonarda (Lone) Klimentova Dersu (oko 1315. - oko 1371.), Šimuna Junijeva Bonu (oko 1345. - 1420.), Marina Lamprina Mençu (oko 1335. - oko 1400.) i druge. ${ }^{11}$ Ponegdje se $u$ ispravama nalaze dodatne informacije o izvršenom povratku zaduženja, prokuratorima koji preuzimaju daljnju isplatu ili novom dogovoru oko isplate zaostalog duga. ${ }^{92}$ Dubrovački su trgovci osim upisa u notarijat vodili i svoje privatne poslovne knjige. Nažalost, vrlo se mali broj ovih knjiga do danas sačuvao. ${ }^{93}$

Tumačenje opsega, vrijednosti i kretanje kreditne trgovine dali smo u grafikonu 1. Poslije kuge 1348., u razdoblju od 1352. do 1355., stanje u trgovini počinje se normalizirati. Upisano je 10 ugovora sa sumom zaduženja

88 O tome više: Vuk Vinaver, Prilozi istoriji plemenitih metala, cena i nadnica (srednjovekovni Dubrovnik), Istoriski glasnik, sv. 1 - 2, Beograd, 1960., 76.

89 Benedikt KotrulJ, Libro del arte dela mercatura. Knjiga o vještini trgovanja, priredila i prevela Zdenka Janeković Römer, Zagreb - Dubrovnik, 2009., 363 - 368.

90 Vidjeti: N. VeKARIć, Vlastela grada 2, 300; N. VeKARIĆ, Vlastela grada 3, 49, 270; Nenad VeKARIĆ, Vlastela grada Dubrovnika 5. Odabrane biografije (E - Pe), Zagreb - Dubrovnik, 2014., 124 - 125, 230; N. VeKARIĆ, Vlastela grada 6, 165 - 166; N. VeKARIĆ, Vlastela grada 7, 70, 366.

91 Vidjeti: N. VeKarić, Vlastela grada 2, 95 - 96, 222; N. VeKarić, Vlastela grada 3, 40; N. VeKARIĆ, Vlastela grada 5, 232; N. VEKARIĆ, Vlastela grada 7, 107; N. VEKARIĆ, Vlastela grada 8, 323.

92 I. VoJe, Kreditna trgovina, 70.

93 Ignacij VoJe, Neki problemi proučavanja ekonomske istorije srednjovjekovnog Dubrovnika: (sa osvrtom na zaleđe), Istorijski glasnik, sv. 1 - 2, Beograd, 1978., 73; Desanka KovaČEvić-Kojıć, Trgovačke knjige braće Kabužić (Caboga): 1426 - 1433, Beograd, 1999., 15 - 20. 
4.622 perpera i 425 dukata. Tijekom 1355. godine nemamo ni jedno kreditno zaduženje. U vrelima nismo našli objašnjenje zbog čega nije bilo trgovačkih aktivnosti Ulcinjana u Gradu. Sljedeće godine u okolini ulcinjske komune vladaju nestabilne političke prilike ${ }^{94} \mathrm{i}$ to se reflektira na samo jedno zapisano zaduženje od 360 perpera. Godine 1357. imamo tri zaduženja (1.102 dukata i 5 groša). Na trgovinu je utjecao i rat Mletačke Republike s Republikom Genovom i kraljem Ludovikom Anžuvinskim. Bilo je tada ratnih operacija i na Jadranu pa je razumno pretpostaviti da su ulcinjski i drugi zetski trgovci čekali ishod rata.

Poslije prelaska dubrovačke komune pod vrhovnu zaštitu ugarsko-hrvatskog kralja, Grad je postao još privlačniji za trgovinu. Nakon ovog događaja dolazi do intenzivnijeg razvitka pomorske trgovine. ${ }^{55}$ Povoljne političke okolnosti te godine utječu povoljno i na zaduženja Ulcinjana. Naredne dvije godine dolazi do smanjenja broja kreditnih transakcija. Trgovinu je ugrozio sukob Dubrovnika s knezom Vojislavom Vojinovićem. ${ }^{96}$ Tijekom 1362. nije bilo kreditnih zaduženja u Gradu. Postoje dva razloga za to: trgovačku djelatnost ugrozila je velika epidemija kuge u Gradu sv. Vlaha. Drugi je razlog da ulcinjska komuna i Grad nisu bili u dobrim odnosima nekoliko mjeseci. Gradske vlasti (svibanj - rujan 1362.) zabranile su izvoz dubrovačke soli u Ulcinj. Bila je određena novčana kazna i oduzimanje soli ako se neko usudi nositi ili dati sol za nekog Ulcinjanina. ${ }^{97}$ Od 1363. do 1367. primjećujemo kolebanja u opsegu kreditne trgovine. Najveći uspon trgovina dostiže 1367. godine, kreditna zaduženja iznosila su 4.401 dukat. $\mathrm{Na}$ ovako visoko trgovačko zaduženje utječu povoljne političke prilike u zaleđu. $S$ druge strane, ulcinjski trgovci proširili su svoju mrežu trgovačkih veza, povećali opseg izvoza i uvoza robe i ulagali u nekretnine.

Neprijateljstvo između Balšića i Karla Topije oko Ulcinja u prvoj polovici 1368. odmah se odrazilo na trgovačke odnose s Gradom. Dolazi do nazadovanja kreditne trgovine u naredne dvije godine. Nisu sačuvane knjige zaduženja za period od 1370. do 1378., zbog čega ne možemo pratiti razvitak kreditne trgovine. Tijekom 1379. i 1380. imamo nekoliko manjih zaduženja. Razlog slabe trgovačke suradnje je rat između Venecije i Genove (1378. - 1381.). ${ }^{98}$ Mletački brodovi nalazili su se u blizini ulcinjske komune. Zapovjednik dubrovačke galije Ivan Đivov Poça (oko 1335. - oko 1409.) trebao je napasti neprijateljske brodove u predjelu Ulcinja. ${ }^{99}$ Početkom ožujka 1379. dubrovački rektor dao je naredbu

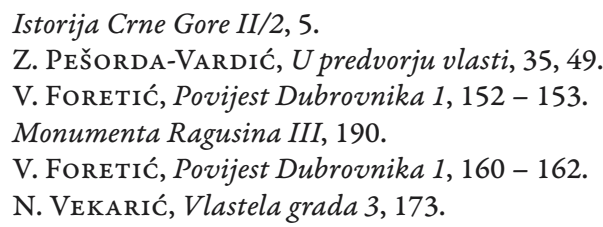


zapovjedniku naoružane lađe Pankraciju (Pokru) Margaritovu Benessi (oko 1330. - 1387.) da pođe do Ulcinja i pohvata sve mletačke brodove i pošalje ih u Dubrovnik. ${ }^{100}$ Sukob je imao negativne učinke na trgovačke odnose u godinama 1378. - 1381. Tijekom 1382. godine upisan je samo jedan kreditni ugovor u iznosu od 124 dukata. Zatim nastaje prekid u dokumentima notarijata, nemamo sliku o kretanju kreditne trgovine do 1389. godine. U 1390. imamo upisana samo dva kreditna zaduženja. Tijekom 1391. i 1392. godine dolazi do povećanja intenziteta trgovine. Kuga je tada harala u Ulcinju, ali nije mogla spriječiti aktivnosti Ulcinjana koji su se nalazili u Dubrovniku.

U razdoblju od 1393. do 1396. imamo smanjen opseg i vrijednost kreditne trgovine. Imamo nekoliko trgovaca iz Ulcinja koji većinom trguju van ulcinjske komune, u Valoni, Dubrovniku ili na bosanskom trgu Drijeva. Kao uzrok stagnacije kreditne trgovine možemo navesti povećanu aktivnost Osmanlija u blizini Ulcinja i sukob ulcinjskog gospodara Đurađa II. i Grada oko naplate carina (1396. - 1398.). ${ }^{101}$

\section{ZNAČAJNIJE TRGOVAČKE OBITELJI}

$\mathrm{Na}$ temelju arhivske građe izdvojili smo istaknutije trgovačke obitelji i trgovce koji su bili najangažiraniji. Opseg njihova poslovanja sagledat ćemo kroz kredite koje su podizali u Dubrovniku. Mnogi od njih vrlo brzo su se uključili u cjelokupni gospodarski i društveni život Grada.

Luka Clime bio je poznati ulcinjski trgovac, plemić i carinik na ušću rijeke Bojane. U povijesnim vrelima spominje se tridesetih godina XIV. stoljeća. Najviše se bavio trgovinom solju. Trgovao je s mletačkim, kotorskim i dubrovačkim trgovcima. Ponekad im je pravio neprilike. ${ }^{102}$ Nekima je to bila dobit, drugima neprilika, ovisno o gledištu. Krajem siječnja 1359. Vido Matov Georgio (oko 1302. - oko 1373.) žalio se dubrovačkom Vijeću da mu je u Ulcinju Luka Clime nezakonito oduzeo sol. Dubrovačka komuna uputila je poslanstvo u Ulcinj, ali nam nije poznato kako se spor okončao. ${ }^{103} \mathrm{U}$ notarskim dokumentima 1362. spominje se da je Nikola, nasljednik Ilije Zagurija, trebao Luki otplatiti dug od 200 perpera. U pitanju je neko ranije zajedničko trgovačko

100 J. TAdić, Pisma i uputstva 1, 373; N. VeKarić, Vlastela grada 2, 65.

101 Marijan Premović, Politički odnosi Đurađa II. Stracimirovića Balšića i Dubrovnika (1385. 1403.), Radovi za povijesne znanosti HAZU u Zadru, sv. 60, 2018., 107 - 112.

102 M. Malović-Đukić, Porodica Kimo, $401-405$.

103 I. Manken, Dubrovački patricijat I, 149 - 151; N. Vekarić, Vlastela grada 5, 13. 
poslovanje između Luke i Ilije, odnosno njegova nasljednika. Luka je umro prije početka lipnja 1366. Tajnu trgovačkog zanata prenio je na svoju obitelj. Poslije njegove smrti kao nasljednici spominju se sinovi llija, Marko, Kimo i udovica Katalena, koji su nastavili poslovanje. ${ }^{104}$ Lukina udovica Katalena i sin Kimo obvezali su se 23. svibnja 1366. da Klimentu (Dragoji) Marinovu Goçi (oko 1348. - oko 1397.) moraju isplatiti 100 dukata i 200 groša od prvog predstojećeg putovanja (do tri mjeseca). ${ }^{105}$ Poslovali su i s dubrovačkom vlastelinskom obitelji Mençe. ${ }^{106}$ Obitelj Clime do 1367. godine prikazana je $\mathrm{u}$ istraživanjima Marice Malović-Đukić. ${ }^{107} \mathrm{Na}$ ovom mjestu donosimo nove podatke i njih posebno ističemo. U travnju 1369. 1lija i Marko izjavili su da su Pavlu (nije navedeno prezime, već samo zanimanje: mačar) dužni 184 dukata, koje će otplatiti od prvog predstojećeg putovanja u roku od četiri mjeseca. ${ }^{108}$ Marko je 23. rujna 1380. namirio dugovanja prema Baziliju (oko 1350. - 1387.) i Franku (oko 1353. - oko 1416.), sinovima Mata Bazilijeva Basilija (oko 1305. - oko 1367.). ${ }^{109}$ Braća Basilio bila su povezana s Ulcinjem preko rodbinske veze njihove majke Bjelče Nikoline Sorgo (oko 1330. - 1382/7.). Bjelčina majka Prva (? - 1401., nismo uspjeli pronaći prezime) de Dulcigno vjerojatno je bila obiteljski povezana s obitelji Clime, a možda i putem poznanstva, pa otuda i suradnja. ${ }^{110}$ Marko se 29. rujna 1380. kod Luke Mihova Bone (oko 1325. 1417.) zadužio 50 perpera. ${ }^{111}$ Istog dana uzeo je kredit od 137 dukata kod Marina Mihova Bone. ${ }^{112} \mathrm{U}$ vrelima nismo našli podatke o daljnjoj kreditnoj aktivnosti. Obitelj Clime poslovala je uspješno, uživala je ugled i povjerenje kod pojedinih dubrovačkih vlastelinskih rodova.

Poznata trgovačka i vlastelinska obitelj iz Ulcinja bila je Bube. Najistaknutiji predstavnik bio je Niko Nikolin Bube. ${ }^{113}$ Rođen je oko 1305., ${ }^{114}$ a umro je oko

104 D. Dinić-Knežević, Migracije stanovnišstva, 212; M. Malović-Đukić, Porodica Kimo, 403, $405-406$.

105 Catalena, uxor quondam Luce de Chimo de Dulcinio et Chimus filius... Deb. Not., sv. 7, f. 45v, (23. 5. 1366.); Vidjeti: N. VEKARIĆ, Vlastela grada 5, $294-295$.

106 N. VeKARIĆ, Vlastela grada 5, 228 - 233; N. VeKarić, Vlastela grada 8, 39 - 49.

107 Iako naslov rada nosi naziv Porodica Kimo-Klimo iz Ulcinja u srednjem veku (14-15. vek), prikazana su samo vrela do 1367. godine. Vidjeti: M. Malović-Đukić, Porodica Kimo, 405 - 406.

108 Deb. Not., sv. 7, f. 181v, (13. 4. 1366.).

109 Deb. Not., sv. 9, f. 29'v, (23.9. 1380.); Vidjeti: N. VeKarić, Vlastela grada 2, 47 - 48; N. VeKARIĆ, Vlastela grada 7, 58; I. MANken, Dubrovački patricijat u XIV veku II: geneološke table, Beograd, 1960., (I. MAN Ken, Dubrovački patricijat II), 5.

110 I. MANKen, Dubrovački patricijat II, 75; N. VeKARIĆ, Vlastela grada 8, 322.

111 Deb. Not., sv. 9, f. 31v, (29. 9. 1380.); Vidjeti: N. VeKarić, Vlastela grada 7, 107.

112 Deb. Not., sv. 9, f. 31v, (29.9. 1380.).

113 I. MANKEN, Dubrovački patricijat I, 160; I. MAN Ken, Dubrovački patricijat II, 19.

114 N. VEKARIĆ, Vlastela grada 7, 93. 
1380. godine. ${ }^{115}$ Bio je oženjen Dekom Šimetom Bodaça (oko 1340. - 1425.).116 Njegov otac Nikola postao je građanin Dubrovnika 7. rujna 1332. godine. ${ }^{117}$ Iz dokumenata saznajemo da je Niko bio trgovac velikog "formata“. Poslovao je s poznatim dubrovačkim trgovcima: Marinom Vidovim Benessom (oko 1330. - 1413.) i Pavlom Nikovim Barabom (oko 1325. - oko 1374.). ${ }^{118}$ Niko se zaduživao kod pet kreditora u različitim iznosima zajma. Prvi se put sam zadužio 7. prosinca 1358. kod Andrije Dobroslavova Binçole (oko 1320. 1400.) u iznosu od 500 dukata. ${ }^{119}$ Iz knjige zaduženja saznajemo da se najviše zaduživao kod vlastelina Marina Vidova Benesse, koji se bavio pomorskom trgovinom i najčešće trgovao žitom. ${ }^{120}$ Priroda njihove veze bila je poslovna i interesna. Dio svog stečenog kapitala Marin je davao Niku na zajam, očekujući da će ga uvećati zajedničkim poslovanjem. Bube je za njega obavljao trgovačke poslove. ${ }^{121} \mathrm{U}$ ljeto 1368 . Niko se obavezao da će obaviti kupovinu žita za Marina zbog prodaje dubrovačkoj komuni. Žito je vjerojatno trebalo biti kupljeno na albanskom primorju (Vrijego ili Davol), gdje je Benessa najčešće trgovao. ${ }^{122}$ Tijekom 1366. Bube uzeo je 30 dukata, ${ }^{123}$ a u partnerstvu je četiri puta (1366. i 1368.) pozajmio 1352 dukata. ${ }^{124}$ Sredinom svibnja 1367 . Niko se obavezao da će Matu Vidovu Georgiju (oko 1329. - 1400.) i Marinu (Maroje) Matovu Georgiju (oko 1345. - 1417.) vratiti 600 dukata. ${ }^{125}$ U siječnju 1368. zadužio se kod Bogdaša Branote i Junija (Ivana) Matijaševa Grade (oko 1335. - oko 1402.) u iznosu od 200 dukata. ${ }^{126} \mathrm{U}$ dva ugovora (1368.) Bube se sam zadužio kod

115 I. MANKen, Dubrovački patricijat II, 19.

116 N. VeKARIĆ, Vlastela grada 7, 93. Nemamo podatke o godini sklapanja braka između Nika i Deke. Njegova je supruga kao miraz dobila kuću u gradu. Početkom lipnja 1387. Deka je posudila dubrovačkoj komuni 225 perpera, koje je dobila od prodaje kuće koja je bila njezin miraz. Kamata je iznosila $5 \%$ za vrijeme dok je komuna držala njezin novac. Deki će komuna novac isplatiti kada ga zatraži. M. J. Dinić, OVDR II, 319 - 320; D. Dinić-KnEžEvić, Položaj žena, 28 - 29.

117 I. Manken, Dubrovački patricijat I, 161; Ruža Ćuk, Trgovci iz zetskih gradova u Dubrovniku i srpskim zemljama u srednjem veku, Srednjovjekovna istorija Crne Gore kao polje istraživanja (ur. Branislav Kovačević), Podgorica, 1999., 163.

118 N. VEKARIĆ, Vlastela grada 2, 42, 68; N. VEKARIĆ, Vlastela grada 7, 52, 80.

119 Nicus de Bube de Dulcinio... Deb. Not., sv. 4, f. 52v, (7. 12. 1358.); Vidjeti: I. Manken, Dubrovački patricijat II, 8; N. VEKARIĆ, Vlastela grada 4, 114.

120 Vidjeti: I. MANkEN, Dubrovački patricijat I, 130; N. VEKARIĆ, Vlastela grada 7, 80.

121 I. Manken, Dubrovački patricijat I, 130.

122 J. Gelcich, Monumenta Ragusina IV, 46.

123 Deb. Not., sv. 7, f. 50v, (24. 7. 1366.).

124 Deb. Not., sv. 7, f. 49v, (15. 7. 1366.); sv. 7, f. 50v, (24. 7. 1366.); sv. 7, f. 148v, (22. 6. 1368.).

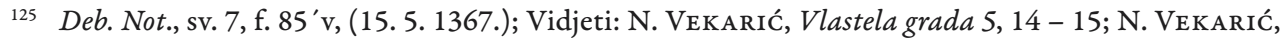
Vlastela grada 7, 299.

126 Deb. Not., sv. 7, f. $126^{\prime}$ v, (30. 1. 1368.); Vidjeti: N. VeKARIĆ, Vlastela grada 5, 75 - 76; N. VeKARIĆ, Vlastela grada 7, 339. 
vlastelina Luke Mihova Bone u iznosu od 187 dukata i Pavla Nikova Barabe u iznosu od 180 dukata. ${ }^{127}$

U dvije priznanice, od 22. lipnja i 16. srpnja 1368., spominje se da je Niko sklopio dva trgovačka partnerstva. Prvo partnerstvo sklopio je s Nikolom Đurovim Cabogom (oko 1320. - 1373.) i zadužio se u iznosu od 700 dukata. ${ }^{128}$ Obiteljska povezanost Nikove i Nikoline žene iz roda Bodaçe usmjerila ih je na međusobnu povezanost. Rodbinske veze utjecale su na stvaranje mreže poslovnih odnosa među trgovcima. ${ }^{129}$ Drugo trgovačko udruživanje bilo je sa Stjepanom Đivovim Georgijem (oko 1320. - oko 1372.) i uzeli su kredit od 222 dukata. Kreditor za oba zaduženja bio je Vido Šimunov Benessa (oko 1295. prije 1368.). ${ }^{130}$ Niko je bio usmjeren na suradnju sa Stjepanom preko zajedničkih partnera Vida i Marina Benessa, s kojima su i za koje su zajednički trgovali. ${ }^{131}$ Marin je bio Stjepanov nećak, njegova sestra Mare (oko 1317. - 1367./80.) bila je udana za Vida. ${ }^{132}$ Sa svima njima blisku trgovačku suradnju imao je Mato Vidov Georgio. ${ }^{133}$ Svoje poslove obavljao je i preko Nika. Tijekom 1368. tražio je od njega nadoknadu štete za 95 stari prosa u vrijednosti 51,5 dukata. Kao razlog navodi da je po Niku 1364. u barci otpremio proso iz albanskog primorja za Dubrovnik, ali su Dračani robu bespravno oduzeli. ${ }^{134}$ Nemamo podatke u vrelima je li i kada je vraćen nastali dug. Vjerojatno je Niko svom partneru nadoknadio štetu u prosu ili novcu. Prirodu navedene grupe pojedinaca i mrežu njihovih veza možemo definirati kroz rodbinske odnose, međusobno poznanstvo i poslovnu suradnju radi financijske dobiti.

U drugoj polovici 1368. Vido Benessa je umro. Niko je sa svojim partnerima Nikolom Cabogom i Stjepanom Georgijem ostao dužan 922 dukata. Krajem veljače 1369. njegov sin Marin dostavlja sudu sedam dužničkih isprava koje je izvukao iz knjige dužnika svog oca. U dvije isprave spominje se dug iz 1368. godine. Marin je kao nasljednik želio naplatiti sva potraživanja. Prenio je sva ovlaštenja na Đuru Jakovljeva Georgija (oko 1330. - oko 1374.) da

127 Deb. Not., sv. 7, f. 148v, (22. 6. 1368.); sv. 7, f. 160v, (13. 10. 1368.).

128 Deb. Not., sv. 7, f. 148v, (22. 6. 1368.); N. Ve KARIĆ, Vlastela grada 7, 193.

129 Nikolina žena Age Nikiforova Bodaçe (oko 1330. - ?) bila je sestrična Nikovoj ženi Deki. I. Manken, Dubrovaćki patricijat II, 10, 19, 22; N. Vekarić, Vlastela grada 7, 193.

130 Deb. Not., sv. 7, f. 111v, (23. 2. 1369.); Vidjeti: N. VeKARIĆ, Vlastela grada 2, 246; N. VeKARIĆ, Vlastela grada 7, 80, 298.

131 J. GeLCICH, Monumenta Ragusina IV, 46, 95.

132 I. Manken, Dubrovački patricijat I, 219. Porodica Bube bila je rodbinski povezana s rodom Georgio, ali ne s obiteljskim ogrankom Stjepanovim, Matovim i Marinovim. Vidjeti: N. VeKARIć, Vlastela grada 7, 80, 298.

133 I. Manken, Dubrovački patricijat I, 218 - 221.

134 I. Manken, Dubrovački patricijat I, 219. 
utjera dug. ${ }^{135}$ Marinova žalba sudu za nepodmirene obaveze ukazuje nam da je moguće da trgovačko društvo nije na vrijeme realiziralo svoju zadaću. Nemamo podatke kako je okončan ovaj slučaj. Teško je precizno utvrditi Nikov financijski status. Kao građanin Grada sv. Vlaha imao je kuću (ne znamo gdje je bila smještena u urbanoj strukturi grada i nemamo podatke o drugim nekretninama), a kroz kreditne isprave vidimo da se bavio posredničkom trgovinom. S obzirom na njegovu intenzivnu angažiranost i dobru povezanost, smatramo da je bio uspješan trgovac.

Drugi istaknuti član obitelji Bube bio je Vitko. U jednoj notarskoj ispravi, od 29. siječnja 1368., on izjavljuje da je poravnata računica s Bogdašem Branotom. ${ }^{136}$ Sutradan se Vito zadužio kod Bogdaša u iznosu od 12 dukata. ${ }^{137}$ Kada govorimo o njegovim kreditnim poslovima, potrebno je naglasiti da je bio slabije „poznat“ $u$ trgovačkim krugovima ili se uopće nije bavio trgovačkom djelatnošću. U dokumentima nismo našli podatke o Vitkovoj godini rođenja i smrti preko kojih bi mogli utvrditi prirodu mogućeg srodstva s Nikom i razliku u godinama između njih.

Više je čimbenika koji utječu na „poznatost“ u trgovačkim krugovima. Na „poznatost“ utječe uspješnost, ali ne i nužno. Uspješan trgovac dobro je umrežen, ima promet i obrt novca, uvećava i unapređuje imetak, poznaje trgovačke običaje, carine i pravila u različitim krajevima, dobar je matematičar i obrazovan je. Njegovu uspješnost karakteriziraju obiteljski život, moralnost, promišljenost, pobožnost, skromnost, suzdržanost, milostivost, lukavost, pravednost, umjerenost i ozbiljnost u odijevanju. Ne smije se kockati, opijati, prejedati, krijumčariti, varati i rasipno se ponašati. Dobar trgovac mora imati tri knjige za poslovanje: podsjetnik, dnevnik i glavnu knjigu. ${ }^{138}$ Navedene predispozicije trebale su biti zadovoljene kako bi netko mogao ostvariti rang uspješnosti.

Od kraja pedesetih godina XIV. stoljeća možemo pratiti trgovačku aktivnost Junija Sevasta iz Ulcinja, iako nije isključeno da se on tim poslovima i ranije bavio. Trgovac Junije zadužuje se u deset kreditnih ugovora. Tijekom 1358. upisan je u tri zadužnice, a 1359 . u dvije. ${ }^{139}$ Krajem prosinca 1359 . Malo vijeće dalo mu je suglasnost da kupi veliku lađu kod magistra Nikole. ${ }^{140}$ Sljedeće godine zadužio

135 N. VEKARIĆ, Vlastela grada 7, 300.

136 Vitcus de Bube de Dolcigno... Deb. Not., sv. 7, f. 126v, (29. 1. 1368.).

137 Deb. Not., sv. 7, f. 126v, (30. 1. 1368.).

138 B. KotrulJ, Libro del arte, 72 - 93.

139 Deb. Not., sv. 4, f. $47^{\prime}$ v, (20. 10. 1358.); sv. 4, f. 152v, (7. 12. 1358.); sv. 4, f. 53v, (11. 12. 1358.); sv. 4, f. $96^{\prime} \mathrm{v},\left(28.12 .1359\right.$.); sv. 4, f. $96^{\prime} \mathrm{v},(31.12 .1359$.$) .$

140 Monumenta Ragusina III, 19. 
se u pet ugovora. ${ }^{141} \mathrm{U}$ ovom kratkom vremenskom razdoblju uzimao je kod Dubrovčana velike iznose na kredit. Ukupan iznos kredita, na temelju podataka iz Debita, iznosio je 1.704,5 dukata. ${ }^{142} \mathrm{Iz}$ ovog zaduženja možemo vidjeti da je opseg poslova toga trgovca dostigao izuzetno velike razmjere. Tijekom 1362. (svibanj - rujan) tražio je od gradskih vlasti lađu na posudbu za putovanje do Stona, ali nije je dobio jer je bila zauzeta. Odlučeno je da može ići lađom tek kad bude slobodna. ${ }^{143}$ Nakon toga nastupa razdoblje tišine njegove trgovačkokreditne aktivnosti. Ne znamo koji su bili uzroci te pojave. Sljedeću generaciju ove obitelji nastavlja njegov sin Marin, koji se bavio trgovinom u znatno manjem opsegu. Sredinom rujna 1367. zadužio se kod obitelj Bona u iznosu od 60 dukata. ${ }^{144}$ Nažalost, nemamo spomena o njegovoj daljnjoj kreditnoj trgovini. Junije je bio imućan trgovac, imao je dobar platežni rang. Njegov sin imao je slabiji financijski status. Nemamo podatke o njihovoj nepokretnoj imovini.

Među Ulcinjanima u Dubrovniku koji su uzimali zajmove nalazimo svećenika don Marina Ivanova. On se prvi put zadužio krajem siječnja 1357. u iznosu od 109,5 dukata. ${ }^{145}$ Godinu dana kasnije upisan je u dva ugovora. Prvoje s Dimitrijem i njegovom braćom uzeo kredit od 46 dukata. Nemamo podatke o njegovim partnerima i njihovoj trgovačkoj djelatnosti. Marin se s bratom Domom, koji se u nekoliko vrela kasnije spominje kao trgovac i notar ulcinjske komune (1397.), zadužio u iznosu od 153,5 dukata. ${ }^{146}$ Do 1377 . Marin je u gradu stekao kuću, a zatim i dubrovačko građanstvo. ${ }^{147}$ Bio je vrlo ugledan, obavljao je značajne poslove za Grad i za Zetu. Kao dubrovački poslanik išao je kod bosanskog kralja

141 Deb. Not., sv. 4, f. 99'v, (8. 1. 1360.); sv. 4, f. 100v, (22. 1. 1360.); sv. 4, f. 100'v, (31. 1. 1360.); sv. 4, f. $100^{\prime} \mathrm{v},(6.2 .1360$.$) ; sv. 4, f. 112^{\prime} \mathrm{v},(20.5 .1360$.).

142 Deb. Not., sv. 4, f. $47^{\prime}$ v, (20. 10. 1358.); sv. 4, f. 152v, (7. 12. 1358.); sv. 4, f. 53v, (11. 12. 1358.); sv. 4, f. $96^{\prime} \mathrm{v},\left(28.12 .1359\right.$.); sv. 4, f. $96^{\prime} \mathrm{v}$, (31. 12. 1359.); sv. 4, f. 99'v, (8. 1. 1360.); sv. 4, f. 100v, (22. 1. 1360.); sv. 4, f. $100^{\prime}$ v, (31. 1. 1360.); sv. 4, f. $100^{\prime}$ v, (6. 2. 1360.); sv. 4, f. $112^{\prime}$ v, (20. 5. 1360.).

143 Monumenta Ragusina III, 190.

144 Deb. Not., sv. 7, f. 100v, (17.9. 1367.).

145 Deb. Not., sv. 3, f. $98^{\prime}$ v, (25. 1. 1357.).

146 Deb. Not., sv. sv. 4, f. 21v, (20. 2. 1358.); sv. 4, f. 41, $112^{\prime}$ v, (15. 9. 1358.); O Marinovu bratu Domeu: Div. Can., sv. 27, f. 46', (19. 10. 1387.); sv. 27, f. 226v, (1. 6. 1389.); Konstantin JirečE K, Romani u gradovima Dalmacije tokom srednjeg veka, Zbornik Konstantina Jirečeka II, Beograd, 1962., $138,339$.

147 D. Dinić-KnežEvić, Migracijestanovništva, 135; O uvjetima za dobivanje dubrovačkog građanstva vidjeti opširnije u: J. MıJušković, Dodjeljivanje dubrovačkog građanstva, 102 - 124; Tomislav RAUKAR, Cives, habitatores, forenses u srednjovjekovnim dalmatinskim gradovima, Historijski zbornik, sv. 29 - 30, Zagreb, 1976. -77., 139-149; Zdenka JANE Ković-RöMER, Građani, stanovnici, podanici, stranci, inovjerci u srednjovjekovnom Dubrovniku, Raukarov zbornik: zbornik u čast Tomislava Raukara (ur. Neven Budak), Zagreb, 2005., 321 - 322; Z. PEšORDA-VARDIĆ, U predvorju vlasti, $86-87$. 
Tvrtka I. u siječnju 1380. godine. ${ }^{148}$ Dubrovačke vlasti zadužuju ga da 29. srpnja 1380. ode u Ulcinj i zatraži od kneza vraćanje đenovskog brigantina. Ulcinjani su bili zaplijenili brod jer je napadao njihove trgovce i plijenio im robu. Kapetan đenovske flote zaprijetio je oštrim mjerama jer njihov brod nije imao namjeru napadati Ulcinj. Napade je izvršio kapetan đenovskog broda na svoju ruku. U sporu je posredovao Marin, savjetujući Ulcinjane da vrate brod sa svim oružjem i priborom. Marin je prijateljski upozorio Ulcinjane da je đenovska flota velika i jaka. ${ }^{149}$ Dubrovačka diplomatska misija nije završila uspjehom, Ulcinjani nisu htjeli odmah popustiti. Krajem studenog 1380. Dubrovčani su morali moliti kapetana đenovske flote da ne napada Ulcinj ni ljude Balše II. Balšića (1378. 1385.). ${ }^{150}$ Vjerojatno su Ulcinjani ubrzo vratili brod Đenovljanima jer u vrelima nismo našli podatke o novom konfliktu. Može se samo reći da je dubrovačka diplomacija i ovom prilikom odigrala presudnu ulogu. Tijekom 1380. i 1381. Marina nalazimo kao dubrovačkog poslanika kod bosanskog kralja Tvrtka I. ${ }^{151}$ Povjeravanjem delikatnih misija dubrovačka mu je vlada ukazivala povjerenje i priznavala mu važan status u društvu.

U kancelariji je 8. studenog 1387. zabilježeno da se Marin Bogojev obavezao da će predati svećeniku Marinu jedan misal. S druge je strane Marin obećao da će mu isplatiti 23 zlatna dukata. ${ }^{152} \mathrm{Uz}$ nekretninu stečenu u Dubrovniku, imao je i posjed u Župi. ${ }^{153}$ U svom rodnom gradu imao je kamenu kuću, koju je prodao 25. svibnja 1387. za 50 dukata Ulcinjanima Valu i Marku. ${ }^{154}$ Svećenik Marin bio je imućan čovjek, o čemu govore novac i nekretnine koje je posjedovao. Zahvaljujući tomu uživao je velik društveni ugled. Međutim, sve je privilegije izgubio 1392. godine. Malo vijeće 21. veljače 1392. kaznilo ga je progonstvom iz Grada i okolice na pet godina. Marinov grijeh bio je taj što dubrovačkim vlastima nije prijavio da je dobio cijelo konavosko selo Uskoplje od kralja Tvrtka 1390. godine. Naime, odlukom Velikog vijeća iz 1374. godine svakom građaninu Dubrovnika zabranjeno je imati ili primiti neko selo na primorju od Boke Kotorske do Neretve i u zaleđu do Nevesinja, uključujući Trebinje i Konavle. Tijekom 1395. godine, uz posredovanje Đurađa II. Stracimirovića Balšića, vratio se u Zetu. U prvoj polovici studenog 1395. Marin je potpisan kao jedan od svjedoka obraćanja

148 Mihailo J. Dinić, Dubrovčani kao feudalci u Srbiji i Bosni, Istoriski časopis, sv. 9 - 10, Beograd, 1959., 141.

149 Lettere di Levante, sv. 2, f. 147 'v, (29. 7. 1380.); J. Tadić, Pisma i uputstva 1, 445 - 446.

150 Mihailo J. Dinić, Odluke veća Dubrovačke republike I, Beograd, 1951., 93.

151 M. J. Dinić, Dubrovčani, 141.

152 Div. Can., sv. 27, f. 55'v, (8. 11. 1387.).

153 Div. Can., sv. 29, f. 135'v, (19. 9. 1390).

154 Div. Can., sv. 26, f. 195v, (25. 5. 1387.). 
zetskog gospodara Veneciji oko pitanja Skadra. Sljedećeg mjeseca imenovan je za barskog nadbiskupa i na toj je poziciji ostao do svoje smrti 1420. godine. ${ }^{155}$

Trgovac Slavko Marinov Slavi najčešće je uzimao kredit u partnerstvu. U rujnu 1358. zadužio se s Pankracijem i Andrijom Ilijinim u iznosu od 360 dukata. ${ }^{156}$ Sredinom travnja 1359. Slavko se zadužuje s Andrijom kod Petra Marinova Bocinola (oko 1303. - 1363.) u iznosu od 326 dukata. ${ }^{157} \mathrm{U}$ četiri navrata zaduživao se zajedno s llijom Markovim iz Ulcinja. Slavko i Ilija posebice su aktivni tijekom 1367. Sredinom veljače uzeli su kredit u iznosu od 500 dukata. ${ }^{158} \mathrm{U}$ lipnju iste godine u tri su navrata pozajmili 2.500 dukata. ${ }^{159}$ Slavko i Ilija imali su veliku razinu zaduženosti u poslovanju, što ukazuje na to da su se upustili u velike trgovačke poslove. Nemamo podatke o njihovu poslovanju. Zaduženost ne mora biti mjerilo uspjeha, već je uspješnost u stalnom prometu i obrtu novca.

Više članova ulcinjske obitelji Dabro uzimalo je zajam od Dubrovčana. U vrelima se navodi da su Dimitrije i Marin (Marinče) bili braća, ${ }^{160}$ a Nikša i Ivan vjerojatno su s njima bili u najbližim rodbinskim vezama. ${ }^{161}$ Obitelj je bila važan dio gospodarskog sustava. Trgovačka djelatnost najbolje se razvijala u obiteljskom krugu. Ekonomska snaga idealno se mogla očuvati kroz složnu i nepodijeljenu obitelj. ${ }^{162}$ Marin se u prosincu 1359. zadužio u iznosu od 40,5 dukata. ${ }^{163}$ U veljači 1360. Dimitrije i Marin Dabro udružili su se s Junijem Sevastom. ${ }^{164}$ Tijekom 1360. i 1361. Dimitrije je sklopio dva kreditna ugovora ukupnog iznosa 465 dukata. ${ }^{165}$ Krajem svibnja 1361. Ivan se spominje u jednom kreditom ugovoru, zadužio se tom prilikom u iznosu od 63 dukata i 5 groša. ${ }^{166}$ U prvoj polovici listopada 1368. Nikša boravi u gradu pod Srđem. Posudio je od Pavla Nikova Barabe 38 dukata. ${ }^{167}$ Marinče je 18. travnja 1369. potpisao ugovor o zajmu (182 dukata) s Marinom Vidovim Benesso m. Osam godina kasnije izdana

155 Vidjeti: D. Dinić-Knežević, Migracije stanovništva, 135 - 136, 211 - 212; Savo Marković, Marin Ivanov, barski nadbiskup 1395 - 1420, Matica, sv. 50, Podgorica, 2012., 189 - 200.

156 Slauçe Marini de Slavi de Dolcigno... Deb. Not., sv. 4, f. 41v, (21. 9. 1358.).

157 Deb. Not., sv. 4, f. $64^{\prime}$ v, (16. 4. 1359.); Vidjeti: N. VeKARIĆ, Vlastela grada 2, 76; N. VEKARIĆ, Vlastela grada 7,85 .

158 Deb. Not., sv. 7, f. 79v, (14. 2. 1367.).

159 Deb. Not., sv. 7, f. 87v, (12. 6. 1367.); sv. 7, f. 88v, (16. 6. 1367.); sv. 7, f. 89v, (17. 6. 1367.).

160 Deb. Not., sv. 4, f. $100^{\prime}$ v, (6. 2. 1360.); sv. 7, f. $182^{\prime}$ v, (18. 4. 1369.).

161 Nixa de Dabro... Johannis de Dabro de Dulcinio... Deb. Not., sv. 7, f. 160v, (13. 10. 1368.).

162 B. KotrulJ, Libro del arte, 81 - 85; Z. Pešorda-VARDić, U predvorju vlasti, 111 - 113.

163 Deb. Not., sv. 4, f. $95^{\prime}$ v, (18. 12. 1359.).

164 Deb. Not., sv. 4, f. 100 'v, (6. 2. 1360.).

165 Deb. Not., sv. 4, f. 113v, (22. 5. 1360.); sv. 5, f. $11^{\prime}$ v, (30. 4. 1361.).

166 Deb. Not., sv. 5, f. 18v, (31.5. 1361.).

167 Deb. Not., sv. 7, f. 160v, (13. 10. 1368.); Nikša se pominje 26. srpnja 1370. kao svjedok u jednoj tužbi. HR-DAD, Lamenta de foris (dalje: Lam. de for.), ser. 52, sv. 1, f. 24'v, (26. 7. 1370). 
mu je priznanica da je dug podmiren i da Benessa ubuduće neće imati nikakvih potraživanja prema njemu. ${ }^{168}$ Vjerojatno se Marinče kasnije ponovo zadužio kod svog vjerovnika, pa otuda i ovaj zapis o nagodbi duga. U vrelima nema podataka o daljem kreditnom zaduživanju ulcinjske obitelji Dabro.

Kao uspješan poslovni čovjek u Knjige zaduženja upisan je Marin Dessi. ${ }^{169}$ On je jedan od poslovnih ljudi iz Ulcinja koji je stigao u Grad krajem pedesetih godina XIV. stoljeća i aktivno se uključio u trgovački život. Tijekom 1359. bio je prisutan u kreditnim transakcijama. U tri kreditna ugovora zadužio se u iznosu od 552 dukata i 10 groša. Njegovi krediti poznati su nam za 1363., 1364., 1365., 1367., 1368. i 1369., dakle gotovo iz godine u godinu. U pet ugovora od 1363. do 1368. posudio je 768 dukata. Inače, u tim ugovorima on se zadužuje sam. ${ }^{170}$ Krajem kolovoza 1368. Marin Dessi se zajedno s llijom Millom zadužio u iznosu od 212,5 dukata kod Pavla (Palče) Vidova Palmote (oko 1320. - 1370.). ${ }^{171}$ Sljedeće godine sam je posudio 290 dukata od istog zajmodavca. ${ }^{172}$ Krajem kolovoza 1380. zadužio se u iznosu od 73 dukata kod Nikole (Niko) Džorina Palmote (oko 1320. - 1381.). ${ }^{173}$ Iz ovih podataka vidimo da je blisko surađivao s obitelji Palmota. ${ }^{174}$ Pavao i Nikola Palmota bili su bratići. ${ }^{175}$ Spominju se kao brodovlasnici i moreplovci, dovozili su žito s albanskog primorja u Dubrovnik. ${ }^{176}$ Imali su bliske rodbinske i poslovne veze $s$ Ulcinjanima preko majčine rodbine Drincasso de Dulcigno. ${ }^{177}$ Vjerojatno su bili i u rodbinskim vezama s Marinom pa se tako može definirati mreža odnosa i priroda veze koja ih je pored materijalne dobiti usmjeravala na međusobnu suradnju. Visoki krediti, koje je Marin Dessi uzimao krajem pedesetih i šezdesetih godina, $s$ kratkim rokovima vraćanja (do tri mjeseca), svjedoče da je imao dobar financijski status. Bio je vrlo sposoban i uspješan trgovac, dobrog platežnog ranga.

168 Deb. Not., sv. 7, f. $182^{\prime}$ v, (18. 4. 1369.); sv. 8, f. $73^{\prime}$ v, (15. 8. 1377.).

169 Marinus de Dessi de Dulcinio... Deb. Not., sv. 4, f. 74v, (15. 7. 1359.).

170 Deb. Not., sv. 4, f. 74v, (15.7. 1359.); sv. 4, f. 96 'v, (31. 12. 1359.); sv. 5, f. 77v, (3. 4. 1363.); sv. 5, f. 77v, (4. 4. 1363.); sv. 5, f. $116^{\prime}$ v, (13. 11. 1364.); sv. 5, f. $131^{\prime}$ v, (4. 6. 1365.); sv. 7, f. $28^{\prime}$ v, (11. 2. 1366.).

171 Deb. Not., sv. 9, f. 25v, (26. 8. 1380.); N. VEKARIĆ, Vlastela grada 7, 42.

172 Deb. Not., sv. 7, f. 179v, (17.3. 1369.);

173 Deb. Not., sv. 7, f. 156v, (31.8. 1368.); N. VEKARIĆ, Vlastela grada 2, 31; N. VEKARIĆ, Vlastela grada 7,42 .

174 Vidjeti: I. Manken, Dubrovački patricijat II, 60.

175 N. VEKARIĆ, Vlastela grada 7, $41-42$.

176 I. Manken, Dubrovački patricijat I, $354-355$.

177 Džore (Đuro) Palmin Palmota (oko 1285. - oko 1327.) oženio je Dobru (oko 1295. - oko 1316.), kćer Picinega Drincassa. Njegov brat Vido Palmin Palmota (oko 1290. - 1316/36.) oženio je drugu kćer Picinega Drincassa, Anu (prije 1324. - 1348.). Vidjeti geneološke table: I. MANKEN, Dubrovački patricijat II, 63; N. VEKARIĆ, Vlastela grada 7, 41. 
Među poznatim Ulcinjanima koji su dobili dubrovačko građanstvo bio je Marin Nikolin. ${ }^{178}$ Postao je građanin oko 1368. godine. ${ }^{179} \mathrm{U}$ prvoj polovici kolovoza 1375. sud ga poziva da povrati dug Jakuši, udovici Lona Derse. ${ }^{180}$ Marinovo kreditno poslovanje može se pratiti u vremenskom razdoblju od 1379. do 1382. godine. Iz zadužnica doznajemo da se u navedenom razdoblju spominje u tri notarska ugovora. U prvoj polovici travnja 1379. Marin i Živko Obradović sklopili su trgovačko ortaštvo. ${ }^{181}$ Krajem lipnja 1379. ugovorio je s Martolom (nije navedeno prezime, već samo zanimanje: bačvar) isporuku bačvi (zapremnine jednog i po milijara) do svetkovine Velike Gospe (15. kolovoza po gregorijanskom kalendaru). Marin je platio zalog od šest perpera, a nakon isporuke bačvi platit će ostatak cijene. ${ }^{182}$ Tijekom 1381. posudio je 196, a 1382. 124 dukata. ${ }^{183}$ Naznačena vrela ukazuju nam da se Marin bavio posredničkom prodajom, što upućuje na pretpostavku da je raspolagao solidnim financijskim sredstvima.

Stjepan Marinov bio je jedan od najpoznatijih poslovnih ljudi. ${ }^{184} \mathrm{U}$ povijesnoj literaturi na temelju dubrovačke građe prikazan je njegov život i poslovna karijera. ${ }^{185}$ Vrlo je često kod Dubrovčana uzimao velike iznose na kredit, koje je na vrijeme vraćao. Njegova trgovačka aktivnost može se pratiti od sedamdesetih godina XIV. stoljeća (tada je trgovao olovom). Dobio je dubrovačko građanstvo 15. prosinca 1388. godine. ${ }^{186}$ Bio je oženjen Marušom (nismo našli točnu godinu u vrelima), kćeri Điva Pavlova Sorga (oko 1345. - poslije 1373.). ${ }^{187}$ Ženidbom s Marušom Sorgo dobio je u miraz posjede u Rijeci dubrovačkoj. ${ }^{188}$ Miraz je ženino vlasništvo, ali je nakon ženidbe njime upravljao muž. Za Stjepana je predstavljao važan kapital $i$ istovremeno dao poticaj razvoju njegovih trgovačkih poslova. ${ }^{189}$

Odmah nakon dobivanja dubrovačkog građanstva, 1389. godine, zadužuje se u svom novom gradu. Iz notarijata se može vidjeti da je bio pojačano kreditno

178 Marinus Nichole de Dulcinio... Deb. Not., sv. 9, f. 86'v, (25. 9. 1381.).

179 R. ĆuK, Trgovci, 164.

180 J. TADić, Pisma i uputstva 1, 313.

181 Deb. Not., sv. 8, f. 163v, (13.4. 1379.).

182 Deb. Not., sv. 8, f. $185^{\prime}$ v, (29.6. 1379.).

183 Deb. Not., sv. 9, f. 86'v, (25. 9. 1381.); sv. 9, f. $146^{\prime}$ v, (27. 9. 1382.).

184 Stefanus Marini de Dulcinio... Deb. Not., sv. 10, f. 32v, (5. 11. 1389.).

185 M. Malović-Đukić, Delatnost Stefana Marinova, 103 - 111.

186 M. MALović-Đukić, Delatnost Stefana Marinova, 107 - 111.

187 Div. Can., sv. 28, f. 68v, (26. 5. 1392.); M. MAlović-Đukić, Delatnost Stefana Marinova, 104. Ovaj podatak dopunjava genealogiju N. Vekarića, Vlastela grada 8, 326.

188 D. Dinić-KNEŽEvić, Migracije stanovništva, 211.

189 Zdenka Jane ković-Römer, Rod i grad. Dubrovačka obitelj od XIII do XV stoljeca, Dubrovnik, 1994., $83-85$. 
aktivan 1389., 1391., 1392. i 1396. godine. Najčešće se Stjepan kao dužnik pojavljuje sam ili u partnerstvu s Marinom Dimitrijevim, Stjepanom Magurčićem i Ivanom Nikolinim. ${ }^{190}$ Dugovani iznos za navedeno vrijeme iznosio je 1.662 dukata. ${ }^{191}$ Stjepan je često bio poslovno odsutan pa je tada sve njegove poslove u gradu obavljala njegova supruga Maruša. ${ }^{192}$ Žena nije mogla obaviti ni jedan posao bez muževljeve suglasnosti. Trgovci su često bili odsutni na duže vrijeme pa da posao ne bi trpio, ovlastili bi svoju ženu da ih zastupa u trgovačkim poslovima. ${ }^{193}$ Krajem svibnja 1392. Maruša prodaje jedan dio svog miraza u Rijeci dubrovačkoj za 200 perpera. ${ }^{194}$ Krajem ožujka 1393. dala je u zakup jedan vinograd i zemlju u Rijeci dubrovačkoj. ${ }^{195}$ To je učinila uz dozvolu muža i komunalnih vlasti jer je u drugoj polovici XIV. stoljeća žena mogla samo tako raspolagati mirazom. ${ }^{196}$

Ulcinjanin Stjepan Marinov osobito se isticao trgovinom solju iz Valone. Od 1391. do 1398. godine dovozio je sol iz Valone u Dubrovnik, ${ }^{197}$ Ulcinj ${ }^{198} \mathrm{i}$ bosanski trg Drijeva. ${ }^{199}$ Najčešće se zaduživao kod vlastelinske obitelji Resti. ${ }^{200}$ Jedan od razloga za uzimanje kredita kod obitelj Resti ležao je u činjenici da je posljednjih godina XIV. stoljeća carinu soli u Valoni držao Mihoč Šimunov Resti. ${ }^{201}$ Stjepan je u nekoliko navrata tijekom 1397. i 1398. zbog investiranja u prodaju soli sklapao trgovačko društvo s Mihočem. Sol je trebalo dopremiti i prodati na trgu u Drijevima. ${ }^{202}$ Osim trgovine, ovaj je Ulcinjanin tijekom svog poslovanja veliki kapital ulagao u pokretna i nepokretna dobra. Osnovni razlog

190 Deb. Not., sv. 10, f. $17^{\prime}$ v, (7. 8. 1389.); sv. 10, f. 23v, (15. 9. 1389.); sv. 10, f. 32v, (5. 11. 1389.); sv. 10, f. $99^{\prime} \mathrm{v},(31.1 .1391$.$) ; sv. 10, f. 110^{\prime} \mathrm{v},(12.5 .1391$.$) ; sv. 10, f. 162^{\prime} \mathrm{v},(8.10 .1392$.$) ; sv. 10, f. 176^{\prime} \mathrm{v},(12$. 12. 1392.); sv. 11, f. 177v, (3. 1. 1396.).

191 Deb. Not., sv. 10, f. $17^{\prime}$ v, (7. 8. 1389.); sv. 10, f. 23v, (15. 9. 1389.); sv. 10, f. 32v, (5. 11. 1389.); sv. 10, f. $73 \mathrm{v},(22.6 .1390$.$) ; sv. 10, f. 99'v, (31. 1. 1391.); sv. 10, f. 110^{\prime}$ v, (12. 5. 1391.); sv. 10, f. 162'v, (8. 10. 1392.); sv. 10, f. $176^{\prime}$ v, (12. 12. 1392.); sv. 11, f. 177v, (3. 1. 1396.); M. MALOvić-Đukić, Delatnost Stefana Marinova, $107-111$.

192 Div. Can. sv. 28, f. 68v, (26. 5. 1392.).

193 D. Dinić-Knežević, Položaj žena, 26 - 27; Z. Janeković-Römer, Rod i grad, 129.

194 Div. Can. sv. 28, f. 68v, (26. 5. 1392.).

195 Dragan Roller, Agrarno-proizvodni odnosi na području Dubrovačke Republike: od XIII do XV stoljeća, Zagreb, 1955., 84.

196 Z. JANEKOvić-RÖMER, Rod i grad, 86, 132.

197 Div. Can., sv. 29, f. 226v, (10.7. 1391.).

198 Petar Baldo, patrun barke, i Andrija Volzo sklapaju ugovor sa Stjepanom Marinovim iz Ulcinja da će njegovom barkom ploviti u Valonu. Tu će utovariti tovar Stjepanove soli i robe i vratiti se u Ulcinj, gdje će iskrcati teret iz barke. Div. Can. sv. 30, f. 8v, (29. 3. 1393.).

199 Div. Can., sv. 32, f. 80v, (29. 8. 1397.).

200 Deb. Not., sv. 10, f. 17 'v, (7. 8. 1389.); sv. 10, f. 32v, (5. 11. 1389.); sv. 10, f. 73v, (22. 6. 1390.); sv. 11, f. 177 v, (3. 1. 1396.); Div. Can., sv. 32, f. 80v, (29. 8. 1397.); sv. 32, f. $138^{\prime}$ v, (6. 5. 1398.).

201 I. MANKen, Dubrovački patricijat I, 391 - 392.

202 Đuro Tošıć, Trg Drijeva u srednjem vijeku, Sarajevo, 1987., 77, 82, 98. 
tomu bila je sigurnost imetka jer su nekretnine bile lišene rizika prisutnog $u$ trgovini. Gradske kuće predstavljale su znak uspona i time je rastao društveni ugled njihovih vlasnika. ${ }^{203}$ Stjepan je, primjerice, imao kuće u Dubrovniku, Ulcinju i Stonu. ${ }^{204}$ Njegova trgovačka djelatnost posljednji se put spominje 15. siječnja 1401., kada je od Ursija (Orsat) Stjepanova (Stepe) Zamagna (oko 1355. - 1427.) uzeo kredit od 128 dukata. Već 27. listopada u dokumentima se spominje kao pokojnik. ${ }^{205} \mathrm{Na}$ temelju navedenih činjenica smatramo da je Marin bio sposoban, uspješan i bogat trgovac.

U zadužnicama se na nekoliko mjesta spominje trgovac Marin Dimitrijev. Osim kredita uzetog u partnerstvu sa Stjepanom Marinovim, zadužio se 1392. i 1394. četiri puta zajedno s ulcinjskim zlatarom Brajkom Miloševićem. Njihovo ukupno zaduženje iznosilo je 1.026 dukata. ${ }^{206} \mathrm{Na}$ temelju dugovanog iznosa mogla bi se izvući premisa da je imao velika zaduženja, ali na osnovi uzimanja velikog kredita ne možemo zaključiti da je bio uspješan trgovac jer to ne potkrepljuju podatci o njegovu trgovačkom prometu.

Vrlo zapažen trgovac bio je Marinče (Marin) Karolli. Potkraj osamdesetih godina XIV. stoljeća počeo je dolaziti u Grad. Zbog krajnje oskudne izvorne građe teško je pratiti njegovu poslovnu karijeru u potpunosti. Tijekom devedesetih godina razvio je iznimno intenzivnu kreditno-trgovačku djelatnost $s$ istaknutim dubrovačkim vlastelinskim rodom Bona. Prvo Marinčetovo zaduženje zabilježeno je 11. listopada 1389. godine. Sljedećih godina pozajmljivao je visoke svote novca koje je na vrijeme vraćao. Tijekom 1392. godišnji iznos je prešao iznos od 600 dukata. Dakle, kako se njegova trgovačka djelatnost uspješno razvijala, tako je rasla i visina njegovih zaduženja. U razdoblju od 1389. do 1396. Marinče više puta boravi u Gradu i zadužuje se 13 puta, što potvrđuje visoki intenzitet poslovanja. ${ }^{207}$ Najčešće je trgovao sa Šimunom Junijevim Bonom (sklopio je pet

203 Zdenka Janeković-Römer, Okvir slobode. Dubrovačka vlastela izmedu srednjovjekovlja i humanizma, Dubrovnik - Zagreb, 1999., 159, 335 - 338; B. KotrulJ, Libro del arte, 467 - 471; Z. PEŠORDA-VARDIĆ, U predvorju vlasti, 171 - 173.

204 M. Malović-Đukić, Delatnost Stefana Marinova, 106 - 110.

205 M. Malović-Đukić, Delatnost Stefana Marinova, 106 - 110; I. Manken, Dubrovački patricijat II, 83; N. VeKARIĆ, Vlastela grada 8, 424.

206 Deb. Not., sv. 10, f. 143 v, (14. 5. 1392.); sv. 10, f. 147 v, (1. 6. 1392.); sv. 10, f. $147^{\prime}$ v, (4. 6. 1392.); sv. 11, f. 109 'v, (18. 11. 1394.).

207 Deb. Not., sv. 10, f. $30^{\prime}$ v, (27. 10. 1389.); sv. 10, f. 85v, (11.10.1390.); sv. 10, f. 107'v, (29.4. 1391.); sv. 10 , f. $149^{\prime}$ v, (12. 6. 1392.); sv. 10, f. $149^{\prime}$ v, (12.6.1392.); sv. 10, f. $159^{\prime}$ v, (26. 8. 1392.); sv. 10, 159'v, (27. 8. 1392.); sv. 10, f. 175 'v, (6. 12. 1392.); sv. 11, f. 28v, (16.6.1393.); sv. 11, f. 46v, (27. 9. 1393.); Marin Karolli obavezuje se na neku isplatu 1394., ali je tu bilješku najvećim dijelom uništila vlaga. Deb. Not., sv. 11, f. 83'v, (25. 6. 1394.); sv. 11, f. 129v, (16. 4. 1395.); sv. 11, f. 177v, (3. 1. 1396.). 
ugovora). ${ }^{208}$ Nemamo podatke o tome kojom su robom trgovali. Iz drugih vrela znamo da su Šimunovi trgovački poslovi bili vezani za vosak, med, olovo, sol itd. ${ }^{209}$ Vjerujemo da su neki od ovih artikala bili predmet njihovih kreditnih ugovora. Marinčetova ukupna zaduženja iznosila su 1.843 dukata i 64 groša. Bio je, očito, vrlo uspješan trgovac.

Marko Tano iz vlastelinske ulcinjske obitelji došao je u Grad devedesetih godina XIV. stoljeća. On se 1393. zadužio kod Marina Đivova Poçe 35 dukata. ${ }^{210}$ Do kraja XIV. stoljeća postao je stanovnik Grada. Obitelj Tano bila je vrlo bogata, zbog toga je primljena u red Antunina tridesetih godina XV. stoljeća, korporaciju najbogatijih trgovaca, brodovlasnika i financijera. ${ }^{211}$

Iz analize strukture dužnika možemo ustvrditi da u ovom razdoblju najveće kredite podiže ulcinjska vlastela. Romanski element kod ulcinjske vlastele prevladava u trgovini. Određen broj Ulcinjana dolazi živjeti u Dubrovnik te nastavlja baviti se trgovačkim poslovima, koje su još više razvili i unaprijedili. Grad im je omogućavao da se upuštaju u velike poslove i da steknu bogatstvo. Najuspješniji trgovci (Marin Nikolin, don Marin Ivanov i Stjepan Marinov) dobivali su dubrovačko građanstvo (cives). Niko Bube naslijedio je građanstvo od svog oca Nikole. Slijede obitelji i trgovci koji su bili stanovnici Grada sv. Vlaha (Chimo, Dessi, Marko Tano i Brajko Milošević), ${ }^{212}$ a nisu imali pravo građanstva (habitatores). Cives i habitatores su zbog boravka u Gradu sv. Vlaha imali veći ugled i, sukladno tomu, bolje osobne veze s dubrovačkim trgovcima, sama komuna nudila je olakšice u transportu robe, zastupanje na trećim tržištima ili pak dopuštenu kupoprodaju nekretnina. Trgovačke obitelji Sevasto i Dabro, trgovci Slavko Marinov Slavi, Marinče Karolli i Marin Dimitrijev nisu bili nastanjeni u Dubrovniku, već su bili stranci formalno nereguliranog statusa (forenses). Kao i mnogi Ulcinjani, u Grad su povremeno dolazili zbog poslova. ${ }^{213}$ Zbog šutnje vrela teško je preciznije odrediti dobnu strukturu trgovaca. Najvjerojatnije su imali izmedu osamnaest i pedeset godina. ${ }^{214}$ Nemamo podatke o njihovu obrazovanju, ali vjerujemo da su skoro svi bili pismeni.

O Šimunu Junijevu Boni vidjeti: I. Manken, Dubrovački patricijat I, 149 - 151; N. VeKarić, Vlastela grada 2, 96.

209 I. MANKen, Dubrovački patricijat I, 150 - 151.

210 Marino de Tano de Dulcinio... Deb. Not., sv. 11, f. 52v, (10.12. 1393.); Nismo našli godinu rođenja i smrti Marina Đivova Poça. Vidjeti: I. Manken, Dubrovački patricijat II, 64.

211 R. ĆuK, Trgovci, 159 - 161, 165; Z. PeŠorda-VARdić, U predvorju vlasti, 43, 47, 110, 148.

212 K. JiREČEK, Romani, 156, 204, 253, 265, 275, 338, 346,

213 Vidjeti: T. Raukar, Cives, 140 - 143; Z. Janeković-Römer, Građani, 321 - 322, 327 - 328; Z. PEŠORDA-VARDIĆ, U predvorju vlasti, 80 - 89.

214 Vidjeti: B. Kot RULJ, Libro del arte, 492 - 497, 500 - 502. 


\section{MANJE POZNATI ULCINJSKI TRGOVCI}

Osim poznatijih trgovačkih obitelji i trgovaca, u dokumentima se javljaju trgovci koji su jednom ili dva puta uzeli kredit. Ulcinjani se spominju u arhivskoj građi 1352. godine u dva kreditna ugovora (1.100 perpera). I. Voje zabilježio je 1353. i 1354. osam ugovora o zajmu, s ukupnom vrijednošću od 3.522 perpera i 425 dukata. ${ }^{215}$ Iznosi zaduženja bili su različiti. Tijekom 1354. Guran se zadužio u iznosu od 425 dukata i 8 groša, a Gergus u iznosu od 111 perpera. ${ }^{216}$ U Knjizi zadužnica od 1356. do 1361. kredite su uzeli: Ivan (360 perpera), Teodor Nikolin (52 dukata i 5 groša), Slavo (1.000 perpera), Frano i Ozroja ( 50 dukata), Ilija Radov (300 perpera), Bile (150 perpera), Darochinis (88 dukata), Dimitrij Campano (55 dukata), Kondo Marinov (40 dukata) i Grdo Suino (70 dukata). Veliki broj dužnika upisan je od 1364. do 1369.: Marin (171 dukat), Stjepan Bogojev (71 dukat), Marin Krinaduzov (65 dukata), Dživo Marinelli (88 dukata), Ilija Pavlov Marini (52 dukata), Dživo pokojnog Luke (164 dukata), Petar Nikolin (49 dukata), Nikola Grube (600 dukata), Džore Volçe (32 dukata), Niko Campano (135 dukata), Džore, nećak Marinov, i Lazar Nikolin (55 dukata). ${ }^{217}$ Među ovim dužnicima posebno se ističe vrijednost zaduženja Nikole Grube. Vjerojatno je kredit planirao usmjeriti u neku investiciju u Dubrovniku, Ulcinju ili na nekom trećem mjestu. U jednom ugovoru, iz rujna 1367., dugovan iznos novca bio je 47 dukata, no nismo mogli identificirati ime zadužnika. ${ }^{218}$ Nekim trgovcima nisu upisana imena, već samo inicijali, ime oca i navedeno je da su iz Ulcinja. Neki P., sin Nikole, izjavio je 22. listopada 1366. da duguje Stjepanu Nikolinom Luccariju (oko 1330. - oko 1414.) 59 dukata. ${ }^{219}$ Dva dana kasnije Džore, sin Nikole Volcina, uzeo je kredit u iznosu od 32 dukata. ${ }^{220}$

215 I. VoJe, Kreditna trgovina, 216.

216 Deb. Not., sv. 3, f. 62v, (18. 4. 1354.); sv. 3, f. 67v, (18. 12. 1354.).

217 Deb. Not., sv. 3, f. $90^{\prime}$ v, (2. 11. 1356.); sv. 3, f. $97^{\prime}$ v, (5. 1. 1357.); sv. 3, f. 107v, (22. 3. 1357.); sv. 3, f. $112^{\prime}$ v, (17. 5. 1357.); sv. 4, f. $18^{\prime}$ v, (17. 1. 1358.); sv. 4, f. $30^{\prime}$ v, (20. 6. 1358.); sv. 4, f. 41v, (22. 9. 1358.); sv. 4, f. $58^{\prime}$ v, (11.2. 1359.); sv. 4, f. 69'v, (11.6. 1359.); sv. 4, f. $78^{\prime}$ v, (16.8. 1359.); sv. 4, f. 95v, (15. 12. 1359.); sv. 5, f. 6v, (14. 2 1361.); sv. 5, f. 18v, (31. 5. 1361.); sv. 5, f. $115^{\prime}$ v, (17. 10. 1364.); sv. 5, f. $119^{\prime}$ v, (7. 1. 1365.); sv. 5, f. 121v, (25. 2. 1365.); sv. 5, f. 124v, (24. 3. 1365.); sv. 5, f. 133'v, (11. 6. 1365.); sv. 7, f. $63^{\prime}$ v, (22. 10. 1366.); sv. 7, f. 100v, (17.11. 1367.); sv. 7, f. 85v, (15. 5. 1367.); sv. 7, f. $112^{\prime} \mathrm{v},(24.10 .1367$.$) ; sv. 7, f. 154v, (11.8. 1368.); sv. 7, f. 161v, (16. 10. 1368.).$

218 < Ego quidem> de Dulcinio confiteor, quod super me et super omnia bona mea usque ad duos menses proxime futuros me obligo dare et solvere Stiepcho de Lucaro ducatos auri XLVII. Et sit de presenti viagio. Et si ultra dictum terminum etc. Renunciando etc. Ser lohannes de Gondola iudex. Giucus de Marculino testis. Deb. Not., sv. 7, f. 99v, (1. 9. 1367.).

219 Deb. Not., sv. 7, f. 63v, (22. 10. 1366.).

220 Deb. Not., sv. 7, f. 112v, (24. 10. 1367.); N. VEKARIĆ, Vlastela grada 7, 399. 
U Debita je upisan Niko Popce. Njegovo ime spominje se u dvama ugovorima. Zadužio se u iznosu od 62 dukata kod Pavla Vidova Palmote 21. siječnja 1368. godine. Istog dana u društvu s Palmotom zadužuje se kod Nikole Marinova Mença na iznos 62 dukata. ${ }^{221}$ Vjerojatno se ovdje radi o udruživanju sredstava za trgovinu. Andrija Sime zadužio se 1. veljače 1369. kod Pavla Vidova Palmote u iznosu od 150 dukata i obvezao se da će ih vratiti u roku od tri mjeseca. Simo nije bio poznat u trgovačkim krugovima pa je stajala klauzula: ako ne vrati zajam u naznačenom roku, vjerovnik ga ima pravo pozvati, tražiti njegovo uhićenje i zatvaranje, kao i zaplijeniti iznos u novcu ili robi. ${ }^{22}$ Kapelan na Lopudu bio je Nikola iz Ulcinja. ${ }^{223} \mathrm{U}$ prvoj polovici lipnja 1369. on se zadužio u iznosu od 28 dukata kod Palka, sluge svećenika Dobre. ${ }^{224}$ Početkom kolovoza 1369. Živko Marinelli zadužio se u iznosu od 32 dukata. ${ }^{225} \mathrm{U}$ gradu pod Srđem 27. studenog 1378. boravio je Tomko Palmich. Tom prilikom posudio je 25 dukata. ${ }^{226}$ Todor Cosuy zadužio se 1380. kod Marina Mihova Bone u iznosu od 29 dukata, u obračunu 30 groša za jedan dukat. ${ }^{227} \mathrm{U}$ jednoj zadužnici iz lipnja 1389. zabilježen je Donko Rosa (zadužio se u iznosu od 65 perpera i 7,5 groša). ${ }^{228}$ Petar i Vali, sinovi pokojnog Ivana, u prvoj polovici prosinca 1395. zadužili su se na malu svotu novca od svega 17 dukata. ${ }^{229}$

Ulcinjani koji se spominju u arhivskoj seriji Debita da samo jednom ili najviše dva puta uzimaju robu na zajam vjerojatno nisu imali daljnjeg uspjeha u trgovačkoj djelatnosti jer se u vrelima više ne pojavljuju, ali to ne znači da nisu uspjeli drugdje. Zbroj svih zaduženja prikazuje ih kao trgovce skromnih razmjera. $S$ druge strane, dovodi se u pitanje koliko kratkoročni zajmovi utječu na njihovu stvarnu trgovačku aktivnost. Pretpostavljamo da su neki zajmovi upotrijebljeni za potrošnju, to jest da su bili neophodni da se preživi neka situacija oskudice i tako dočeka novi prihod.-

Iz fragmentarne analize dužnika vidimo da su bili iz različitih društvenih slojeva. Najveći broj dužnika bio je iz reda pučana. Zapisana su pučanska imena Kondo Marinov, Bile, Marin Krinaduzov, Ilija Radov itd. ${ }^{230}$ Dužnici su pripadali

Deb. Not., sv. 7, f. 125v, (21. 1. 1368.); N. VE KARIĆ, Vlastela grada 8, 41.

Deb. Not., sv. 7, f. 173v, (1. 2. 1369.).

D. Dinić-Knežević, Migracije stanovništva, 135.

Deb. Not., sv. 7, f. 200v, (10.6. 1369.).

Deb. Not., sv. 7, f. $208^{\prime}$ v, ( 4. 8. 1369.).

Deb. Not., sv. 8, f. 130 'v, (27. 11. 1378.).

Deb. Not., sv. 9, f. $10^{\prime}$ v, (28. 5. 1380.).

Deb. Not., sv. 10, f. 1v, (12.6. 1389.).

Deb. Not., sv. 11, f. 174v, (9. 12. 1395.).

Vidjeti: K. JiRečE K, Romani, 214 - 216, 230 - 231. 
sitnoj ulcinjskoj vlasteli i malim trgovcima. Među upisanima nalazimo pripadnike vlastelinskih rodova Campano, Suino, Marinelli, Grube, Popce, Palmich, Cosuy, Rosa itd. ${ }^{231} \mathrm{Na}$ temelju pojedinih spomena u dokumentima teško je odrediti imovinsko stanje navedenih pučana i vlastele.

\section{TRGOVAČKA DRUŠTVA}

Komune na istočnojadranskoj obali bile su dio zapadnog europskog gospodarskog sustava. ${ }^{232} \mathrm{U}$ njima je prakticiran rad kroz trgovačka društva. ${ }^{233}$ Glavni motiv sklapanja trgovačkog društva (societas) bilo je stjecanje većih financijskih sredstava i zaštita poslovanja, tj. da u slučajevima neuspjeha članovi društva lakše podnesu gubitak. Najčešći oblik udruživanja u ovom razdoblju bila je kolegancija (collegantia). Bogatiji trgovac (socius stans) najčešće je ulagao novac, dok je drugi član društva (socius tractans) poslovao uloženim sredstvima i sudjelovao svojim radom. Prvi je ostajao u Dubrovniku, dok je drugi putovao u Zetu ili negdje drugdje, gdje su to već poslovi zahtijevali. Dobit ili šteta u društvu dijelila se na dva jednaka dijela. ${ }^{234}$ Ulcinjani su u Gradu obavljali trgovačke poslove pomoću trgovačkih društava. U okviru društava, na kraće ili duže vrijeme, povezivala su se dva suradnika iz redova trgovaca.

U srpnju 1366. Niko Bube je na ime trgovačke udruge ili koleganse primio 430 dukata od Marina Vidova Benesse Imao je rok od šest mjeseci da uloži novac, a zatim je trebao ispostaviti račun i isplatiti polovicu dobiti ili „ne daj Bože“ štete. ${ }^{235}$ U kolovozu 1368. Niko Campano primio je od Marina Benesse 135 dukata na ime koleganse. Bio je obvezan Marinu položiti račun u roku do šest

231 K. JirečE K, Romani, 189, 257, 270, 354.

232 O srednjovjekovnom obliku zapadnog „feudalizma“ postoji više studija koje ga problematiziraju, na ovom mjestu dajemo samo izbor: Francois Louis GAnshof, Feudalism, New York, 1964.; John S. Critchley, Feudalism, London - Boston, 1978.; Igor Filippov, The Notion of Feudalism in Russian Historiography, El temps i l'espai del feudalisme (ed. Flocel Sabaté and Joan Farré), Lleida, 2004., 149 - 165; Susan Reynolds, The Middle Ages without Feudalism: Essays in Criticism and Comparison on the Medieval West, Farnham, 2012.

233 Tomislav RaukAR, Splitska trgovačka društva XIV. stoljeća, Med Srednjo Evropo in Sredozemljem: Vojetov zbornik (ur. Sašo Jerše, Darjo Mihelič i Petar Štih), Ljubljana, 2006., 379 - 381.

234 Osnovna pravila o trgovačkom društvu kolegancija određena su dubrovačkim statutom iz 1272. godine. O tome: Statut grada Dubrovnika, 196 - 199, 402 - 403; Tomislav RAUKAR, Zadar u XV stoljeću: ekonomski razvoj $i$ društveni, Zagreb, 1977., 268 - 274; Ignacij VoJE, Prilog proučavanju dubrovačkih trgovačkih društava, Zbornik radova u čast akademiku Desanki Kovačević Kojić (ur. Rajko Kuzmanović, Dragoljub Mirjanić i Đuro Tošić), Banja Luka, 2015., 175-187.

235 Deb. Not., sv. 7, f. 50v, (24. 7. 1366.). 
mjeseci. ${ }^{236}$ Živko Obradović sklopio je 13. travnja 1379. ugovor o stupanju u trgovačko društvo s Marinom Nikolinim. Obradović je primio 60 perpera kao ulog koje će iskoristiti za kupnju žita. Zarada ili šteta dijelila se na pola. Živko se obvezuje ispostaviti Marinu račun, ali ako on ne bude prisutan u Gradu, račune će polagati Marinovoj supruzi Petri. ${ }^{237}$ Žene su u odsustvu muža često uživale povjerenje da se brinu o njihovoj trgovačkoj robi. ${ }^{238} \mathrm{U}$ ovom slučaju ne možemo sumnjati da se radilo o gotovinskom zajmu. Početkom prosinca 1392. godine Ulcinjanin Vale sklopio je trgovačku udrugu s Utješinom Radosalićem, koji je uložio u društvo 300 perpera. Vale je imao tri mjeseca za trgovanje tim novcem. ${ }^{239}$ Nije bilo navedeno koliko su vremenski trajala trgovačka društva. Vjerojatno su bila osnovana/utemeljena zbog obavljanja isključivo jednog posla (od tri do šest mjeseci).

\section{TRGOVAČKA ROBA}

Ulcinjani su s Dubrovčanima sklapali društva, ili su samostalno djelovali, zbog trgovine soli, žitom, vinom, voskom, lađama itd. Najčešće su ulcinjski trgovci bili uključeni u opskrbu soli i žita. Sol je bila neophodna za ishranu stanovništva i stoke, za konzerviranje mesa i ribe te spravljanje stočarskih proizvoda. ${ }^{240} \mathrm{Za}$ Ulcinj bilo je vrlo važno što se u blizini nalazio Trg sv. Srđa. U vrelima se spominje da su dubrovački trgovci dovozili sol iz Valone i prodavali na

237 Deb. Not., sv. 8, f. 163v, (13. 4. 1379.). Žito je jedan najvažnijih artikla prehrane na dalmatinskom primorju. Dubrovnik ga je najviše nabavljao u Apuliji, Levantu (zemlje istočnog Sredozemlja), Bosni, zetsko-albanskom primorju i južnoj Albaniji. Uobičajena mjera za žitarice bio je starij, star (starium). Star je bila mjera za volumen, po današnjoj decimalnoj mjeri iznosio bi: 1 starium $=$ oko $65 \mathrm{~kg}$ do 71,5 kg. I. Manken, Dubrovački patricijat I, 103 - 104. Usporedi: Tomislav RaukaR, Prilog poznavanju sistema prihoda dalmatinskih gradova u XIV. stoljeću, Historijski zbornik, sv. XXI - XXII, 1968. - 1969., 360 - 361. Cijena jednog stara žita tijekom 1376. - 1377. iznosila je od 44 do 48 dinara, a kasnije se mijenjala. Bogate žetve oborile su cijenu u srpnju 1379. na 22, a sljedećeg mjeseca na 25,5 dinara. Do kraja 1379. cijena je iznosila 36 dinara. Ovo nam govori da je cijena varirala i da je ovaj artikal bio iznimno važan za trgovinu. Ako bi ga trgovac kupio na vrijeme, zbog velike je potražnje na žitu mogao dobro zaraditi. V. VinaVer, Prilozi istoriji, 57. O uvozu i izvozu žita iz srednjovjekovnog Dubrovnika u XIV. stoljeću vidjeti: Dušanka DinIćKnežEviĆ, Trgovina žitom u Dubrovniku u XIV veku, Godišnjak Filozofskog fakulteta, sv. 10, Novi Sad, 1967., 79 - 131.

238 Vidjeti: D. Dinić-KnežEvić, Položaj žena, 10, $25,27$.

239 Deb. Not., sv. 10, f. $174^{\prime}$ v, (2. 12. 1392.).

240 O trgovini solju vidjeti opširnije u: M. Gecić, Dubrovačka trgovina, 95 - 153. 
ovom trgu. ${ }^{241}$ Početkom proljeća 1376. ulcinjski knez Nikola potvrđuje da mu je dovezena sol iz Brindizija. ${ }^{242} \mathrm{U}$ drugoj polovici lipnja 1398. Mato Vidov Georgio i Vale iz Ulcinja ugovaraju poslovno udruženje zbog prodaje soli iz Valone. ${ }^{243}$ Stjepan Marinov 6. svibnja 1398. obavezuje se na isplatu soli, ${ }^{244}$ a u kolovozu 1398. prenosi sol za prodaju na Neretvi. ${ }^{245}$

Žito je strateški proizvod (još više nego sol) i trgovina ovim artiklom pružala je mogućnost zarade, stjecanja imetka i društvene afirmacije. Već smo spomenuli da su Niko Bube i Marin Nikolin trgovali žitom. U arhivskoj građi nalazimo podatke o trgovini ovim artiklom. Da bi se žito izvezlo iz grada, bila je potrebna dozvola Velikog vijeća. ${ }^{246}$ Taj izvoz nije bio u većim količinama. Početkom 1386. godine došlo je do nestašice žita u gradu pa je zbog toga u ožujku 1386. Malo vijeće poslalo Maroja Xucha u Ulcinj super facto grani. ${ }^{247}$ Cijena žita 1386. godine skočila je s 30 - 45 na nepunih 60 dubrovačkih dinara. ${ }^{248}$ U siječnju 1388 . Valu iz Ulcinja dozvoljeno da kupi do 6 stari pšenice. ${ }^{249}$ Približni proračun po današnjoj decimalnoj mjeri za 6 stari pšenice iznosilo bi oko 390 do $429 \mathrm{~kg}$. ${ }^{250}$ Početkom ožujka 1388. godine ulcinjskom gospodaru Balšiću odobrena je molba da može kupiti do 50 stari žita, po cijeni od 4 perpera za star. ${ }^{251}$ Grad je te godine imao veću količinu žita i dozvolio je izvoz uz suglasnost kneza i Malog vijeća. ${ }^{252}$

Osim žitom i solju, trgovalo se i vinom. U Dubrovniku je ono spadalo u proizvod ishrane, tako da je briga Grada za ovo piće dolazila odmah poslije brige za žito. ${ }^{253}$ Krajem listopada 1390. Grad dozvoljava izvoz 200 quinqua vina Antibar vel Dulcinii. ${ }^{254}$ U proljeće 1393. godine, u jednom ugovoru o plovidbi,

241 Jedan od posljednjih utovara iz Valone za Sv. Srđbio je 1390. godine. Nakon prijelaza pod mletačku vlast 1396. Sv. Srđ izgubio je pravo prodaje soli na širokom području Bojane. B. HRABAK, Promet soli, 97.

242 Div. Can., sv. 24, f. 128v, (25. 3. 1376.).

243 Div. Can., sv. 32, f. 154v, (20.6. 1398.).

${ }^{244}$ Div. Can., sv. 32, f. $138^{\prime}$ v, (6. 5. 1398.).

${ }_{245}$ Div. Can., sv. 32, f. 172v, (17. 8. 1398.).

246 D. Dinić-KnežEvić, Trgovina žitom, 79 - 131.

247 M. J. Dinić, OVDR II, 260; D. Dinić-KNEŽEvić, Trgovina žitom, 109.

248 V. VinaVer, Prilozi istoriji, 57.

249 M. J. DiNIĆ, OVDR II, 253.

250 I. MANKEN, Dubrovački patricijat I, 104.

251 M. J. DiNIĆ, OVDR II, 404.

252 D. DiniĆ-KNEŽEvić, Trgovina žitom, 110 - 111.

253 Dušanka Dinić-KnežEvić, Trgovina vinom u Dubrovniku u XIV veku, Godišnjak Filozofskog fakulteta, sv. 19, Novi Sad, 1966., 83 - 84.

254 Savo Marković, Stanovništvo srednjovjekovnog Bara, Perast, 2014., 317. Vino se mjerilo u kvinkvima. U prodaji na veliko koristio se quinquo grande, a u prodaji na malo quinquo piçolo. Današnja vrijednost izgledala bi ovako: 1 quinquo grande $=$ oko 21 litra; 1 quinquo piccolo $=$ oko 183/4 litra. I. MAN Ken, Dubrovački patricijat I, 104. 
Marin Petrov kupuje od Andrije Volcija vino za prodaju u Ulcinju. ${ }^{255}$ Nismo uspjeli naći daljnje obavijesti o trgovini vinom.

Tkanine su bile jedan od važnih izvoznih proizvoda Dubrovčana. Krajem kolovoza 1361. Veliko je vijeće dozvolilo Ulcinjanima koji su boravili u gradu da mogu kupovati za svoje odijevanje najmanje pola komada pecije tkanine. ${ }^{256}$ Nemamo podataka u vrelima o daljem trgovanju s tkaninama. Iz Dubrovnika se uvozio vosak. Dome, brat svećenika Marina, preuzeo je vosak iz Grada u listopadu 1387. godine, s zadatkom da ga isporuči i proda u Ulcinju. ${ }^{257}$

Drvo je predstavljalo jedan od najznačajnijih predmeta izvoza iz Ulcinja u Grad. Najviše je korišteno za izgradnju čamaca, brodova, koliba, bačvi i sitnog inventara za pokućstvo. Komuna se za izgradnju brodova opskrbljivala drvom s Bojane. Dubrovčani su uvozili tri vrste drva iz okolice Ulcinja: hrast, topolu i vrbu. ${ }^{258}$ Drvo su na mjestu sječe najčešće pripremali drvodjelci i bačvari. Poslodavci su im plaćali od 4 do 6 perpera mjesečno i davali hranu. Pavle Baraba 20. rujna 1367. kod dvojice drvodjelaca naručuje da mu pripreme drvo za izgradnju jedne barke. Drvo je trebalo biti spremno do Božića, kada će biti utovareno na ušću Bojane po cijeni od 140 perpera. ${ }^{259}$ Početkom siječnja 1390. Bogoje iz Ulcinja obvezuje se opatu lokrumskog samostana na isporuku drvene građe. ${ }^{260}$ Drvodjelci Bogdan i Bogoje Dobrosalich obvezuju se (20. studenog 1397. - 13. veljače. 1398.) Andriji Rusiću na isporuku drva za gradnju broda koje će ukrcati na nekom mjestu od Ulcinja do Bojane. ${ }^{261}$ Drvo se 13. srpnja 1398. tovarilo u ulcinjskoj luci Algirani. Prebacivanje iz Ulcinja do Dubrovnika koštalo je 150 perpera. ${ }^{262}$ Trgovalo se i lađama. Krajem ožujka 1377. Marinče Sorgo iz Ulcinja izjavljuje da je Pasku Matovu Restiju (oko 1350. - 1438.) i đakonu Frederiku prodao barku usidrenu u dubrovačkoj luci za 30 perpera u gotovom novcu. ${ }^{263}$ Deset godine kasnije Luka Mihov Bona prodao je

255 Div. Can., sv. 30, f. 8v, (29. 3. 1393.).

256 Monumenta Ragusina III, 113.

257 Div. Can., sv. 27, f. 46', (19. 10. 1387.).

258 Dušanka Dinić-Knežević, Trgovina drvetom u Dubrovniku u XIV veku, Godišnjak Filozofskog fakulteta, sv. 14/1, Novi Sad, 1971., 9 - 29; Bogumil Hrabak, Arbanaško drvo u Dubrovniku, Historijski zbornik, god. 37, br. 1, Zagreb, 1984., 62 - 66.

259 Div. Can., sv. 21, f. $128^{\prime}$ v, (20.9. 1367.).

260 Div. Can., sv. 29, f. $48^{\prime}$ v, (7. 1. 1390.).

261 Div. Can., sv. 32, f. 71', (4. 8. 1397.).

262 M. Malović-Đukić, Privredne veze, 65.

263 Marinçe de Sorgo de Dulcinio faciunt manifestum facit manifestum, quod ipsi vendidit unam suam barcham, quam habet in portu Ragusii cum omnibus suis affixis et corredis ser Pasche de Resti et dyacono Frederico de Goçe pro ypperperis triginta, quos fuit confessus habuisse ab ipsis. Deb. Not., sv. 8, f. 23, (25. 3. 1377.). O Pasku Matovu Restiju vidjeti: N. VEKARIć, Vlastela grada 6, 127 - 128. 
barku Petruču iz Ulcinja. ${ }^{264} \mathrm{U}$ dokumentima nalazimo i na upisane ugovore o ustupanju lađa za plovidbu od Grada do Ulcinja. ${ }^{265}$

O predmetima trgovine dragocjene podatke pružila nam je serija Diversa Cancelariae. Ulcinjski trgovci bavili su se posredničkom trgovinom i najčešće su iznajmljivali barke od Dubrovčana za prijenos robe iz Grada do Ulcinja. Prateći trgovačku djelatnost, identificirali smo da se trgovalo tada najtraženijim artiklima. Na temelju navedenih podataka indirektno zaključujemo da je u zadužnicama naznačena trgovačka roba (sol, žito, vino, tkanine i vosak) najčešće bila predmet kreditne trgovine.

\section{KREDITNE GARANCIJE}

Stanovnici iz zaleđa koji su u Dubrovnik dolazili podignuti kredit najčešće su dobivali zajam kada je dužnikova imovina bila dovoljna garancija. I o ovome je ranije bilo govora. Imovina je morala odgovarati vrijednosti traženog zajma. Ako nisu postojala takva osiguranja, u dokumentima kreditnih zadužnica navođena su jamstva. Jamci su morali biti osobe koje su mogle svojim osobnim autoritetom i imetkom pružiti kreditoru potrebne garancije. Kredit su dužnici dobivali na temelju garancija jamaca, davanja zaloga i jamstva prokuratora. Trgovci koji su dolazili u Dubrovnik prvi put ili nisu bili dovoljno poznati često su dobivali kredit samo na temelju tih jamstava. $\mathrm{Na}$ temelju navedenih garancija kreditor je bio zaštićen da će dužnik do roka vraćanja zajma ispuniti svoju kreditnu obavezu. Poznatije trgovačke obitelji, koje su imale česte poslovne veze s istaknutijim stanovnicima Grada, dobivale su zajmove bez garancija. Oni su uživali povjerenje i dobivali relativno visoke kredite kao pojedinci ili udruženi u trgovačka društva. ${ }^{266}$

\section{Jamci}

Jamac je garantirao svojom imovinom da će dužnik, do dana dospijeća, ispuniti svoju kreditnu obvezu. U zadužnicama se ta osoba naziva plecius, plegius, fideiussor, a jamstvo pleçaria, plegiaria. Dužnik je obično imao jednog jamca, a prema zahtjevu vjerovnika moglo ih je biti i više. Ako dužnik ima dva ili više jamaca, oni su obično garantirali podjednako za čitav iznos. Ako dužnik nije podmirio dug na vrijeme, tada je vjerovnik od jamca tražio da podmiri dug u

Div. Can., sv. 22, f. $91^{\prime}$, (4. 8. 1369.); sv. 29, f. 92', (5. 5. 1390.); sv. 32, f. $151^{\prime}$, (13. 6. 1398.).

I. VoJe, Kreditna trgovina, 120 - 130; I. VoJE, Poslovna uspešnost, 58 - 63. 
cijelosti ili samo onaj dio duga koji nije bio vraćen. Nakon podmirenja duga jamac je dobivao potvrdu da je oslobođen obveze. ${ }^{267}$ Zanimljivo je da se jamci ne spominju često u zadužnicama ulcinjskih trgovaca. Neki trgovci koji su bili na samom početku karijere imali su jamstva. Tako je 28. svibnja 1380. godine Todor Cosuy podigao kredit, a kao jamac spominje se krojač Domanja (Dominče). ${ }^{268}$ Marko Clime 23. rujna 1380. dostavlja sudu pisanu presudu od 5. siječnja 1380. na temelju oporuke Draže (? - prije 1381., nismo uspjeli pronaći prezime), supruge Dima Vlahova Mença (oko 1295. - 1363.). Pokojnica je dugovala 500 perpera i potpisala da ih mogu naplatiti od njezinih dobara čim ona umre. Ako njezina ostavština ne bude dovoljna, sud će zaplijeniti imovinu njezina jamca Bahoja (Bazilije) Matova Basilija (oko 1350. - 1387.), koji je garantirao da će kredit biti vraćen. ${ }^{269}$ Iz ovog slučaja vidimo da jamac nije uvijek jamčio za cijeli iznos, nego za manji dio zajma koji nedostaje. Jamac je imao veliku odgovornost, garantirao je svojom imovinom da će zajam biti vraćen kreditoru. Nismo uspjeli utvrditi kakva je veza između jamca Bahoja i udovice Draže. Kao što smo spomenuli, obitelj Basilio bila je poslovno i vjerojatno rodbinski povezana s obitelji Clime. $\mathrm{Na}$ temelju toga možemo zaključiti da su oni su bili pouzdani jamci za vraćanje spomenutog duga. Važnu ulogu igrala je činjenica da su ti Ulcinjani imali dubrovačko građanstvo ili barem boravište u Dubrovniku.

\section{Zalog}

U dokumentima se za zalog najčešće upotrebljava termin pignus. Vrijednost zaloga (predmeta) morala je odgovarati vrijednosti kredita. U zalog su obično davani srebrni predmeti (čaše), ${ }^{270}$ pojasevi, ${ }^{271}$ haljine, ${ }^{272}$ dugmad, ${ }^{273}$ posuđe, ${ }^{274}$ komadi sirovog srebra, ${ }^{275}$ tkanine, ${ }^{276}$ vino $^{277}$ itd. Dužnik je mogao dati vjerovniku

Ego quidem Thodor Chosuy de Dulcinio tres menses proxime venturos me obligo dare et solvere ser Micaeli quondam Iunii de Bona ducatos auri viginti novem ad racionem grossorum triginta pro quolibet dictorum ducatorum. Et sit de presenti viagio. Et si ultra dictum terminum etc. Et Domincze sartor constituit se plegarium et pagatorem ipsi ser Micaeli pro dicto Thodoro ad dictum terminum. Renunciando etc. Ser lohannes de Grede iudex et. Maroe scribanus sclavicus comunitatis testis. Deb. Not., sv. 9, f. 10'v, (28. 5. 1380.).

269 Deb. Not., sv. 9, f. 29'v, (23. 9. 1380.). Vidjeti: I. Manken, Dubrovački patricijat II, 5, 57; N. VEKARIĆ, Vlastela grada 7, 58; N. VeKARIĆ, Vlastela grada 8, 39,

270 Div. Can., sv. 12, f. 86v, (2. 5. 1335.).

271 Div. Can., sv. 12, f. 172 'v, (11. 11. 1335.); sv. 15, f. 56v, (15. 11. 1347.); sv. 24, f. 147v, (26. 5. 1376.).

272 Div. Can., sv. 27, f. 226v, (1.6.1389.).

273 HR-DAD, Testamenta Notariae, ser. 10, sv. 15, f. 149' - 150'v, (16. 7. 1455.).

274 Deb. Not., sv. 32, f. 167v (8. 1. 1459.).

275 Div. Can., sv. 22, f. $86^{\prime}$ v, (10. 10. 1370.). 
i nepokretnu imovinu. ${ }^{278}$ Ugovor je sadržavao klauzulu po kojoj je povjeritelj trebao vratiti zalog kada dužnik podmiri dug. Po isteku određenog roka za otkup zaloga, ako se dug ne bi podmirio, založeni predmeti prodavani su na javnoj dražbi. U tom slučaju primjenjivan je poseban postupak. ${ }^{279} \mathrm{Na}$ zahtjev svećenika Marina Ivanova iz Ulcinja, Janje, glasnik dubrovačke komune, dobio je nalog (21. svibnja 1377.) od kneza Pavla Andrijina Sorga (oko 1305. - prije 1383.) i gradskih sudaca da pozovu Dražu, suprugu pokojnog Bogdana Okruglog. Ona je trebala otkupiti založene pojaseve i dostaviti potvrdu o uplati (nije naveden novčani iznos) kancelariji. ${ }^{280}$ Poslije suprugove smrti sva prava i obaveze formalno su prelazile na njihove žene. ${ }^{281}$ Kao nasljednica muževih dugova, udovica Draža se nije odazvala, nije se pojavila u Gradu. Sigurno nije bila u financijskoj situaciji da podmiri raniji dug svog supruga, pa su zbog nepoštivanja ugovora pripali Marinu. Četiri dana kasnije on je izjavio da je preuzeo priznanicu založenog pojasa od kancelara Todora. ${ }^{282}$ Zalog zamjenjuje potraživanje: vjerovnik dobiva predmet umjesto novca koji je dao dužniku. Taj oblik kreditiranja predstavljao je za vjerovnika mnogo manji rizik negoli obični zajmovi. ${ }^{283}$ Ulcinjska komuna 17. svibnja 1380. vratila je devet libara srebra Matu Vidovu Georgiju, dug što je kod njega zadužio Tripo, sin pokojnog Nikole Suselcha, u Prizrenu. Dubrovačke vlasti bilježe da su poslale ulcinjskim vlastima ispravu i da je ona upisana $u$ gradske knjige Dubrovnika i Ulcinja. ${ }^{284}$

Zalog je jedan od oblika uzimanja ne samo trgovačkog već i potrošačkog kredita. Zetski gospodari braća Stracimir i Đurađ I. Balšić obavještavaju Dubrovčane pismom (27. lipnja 1368.) da se kod njihova trgovca i kreditora Rajnolda Stambertisa (sin dubrovačkog kancelara Pona) nalazi Stracimirov zlatni pojas. Stoga su poslali svog čovjeka Dmitra Dabra iz Ulcinja da podigne založeni zlatni pojas. Krajem lipnja 1368. on je boravio u Gradu sv. Vlaha kao poslanik braće Balšić da bi podigao Stracimirov pojas od Rajnolda. Na kraju pisma oni mole Dubrovčane da ispoštuju njihova čovjeka i da su obveze prema

276 Div. Not., sv. 13, f. 68v, (9.11.1418.).

277 Deb. Not., sv. 2, f. 122', (24. 10. 1336.).

278 Deb. Not., sv. 2, f. 53v, (21. 9. 1335.).

279 O zalogu kao obliku kreditiranja vidjeti više u: I. VoJe, Kreditna trgovina, 124 - 128; Jelena DANilović, Zaloga u starom dubrovačkom pravu, Anali Pravnog fakulteta u Beogradu, sv. 35, br. 6, Beograd, 1987., 637 - 662; I. VoJe, Poslovna uspešnost, 61.

280 Deb. Not., sv. 8, f. 41v, (21. 5. 1377.); I. MANKen, Dubrovački patricijat II, 74; N. VE KARIĆ, Vlastela grada 3, 260.

281 D. Dinić-Knežević, Položaj žena, 110, 113.

282 Deb. Not., sv. 8, f. 42v, (25. 5. 1377.).

283 J. DANilović, Zaloga, 635 - 656.

284 Deb. Not., sv. 9, f. 10v, (28. 5. 1380.); Vidjeti: I. MANken, Dubrovački patricijat I, $219-221$. 
kreditoru bile izmirene. ${ }^{285}$ Početkom lipnja 1389. na zahtjev Dome iz Ulcinja prodaje se haljina, založena zbog duga od devet perpera i četiri groša. Pošto se nije pojavio kupac koji bi ponudio više, prodana je za sedam perpera. ${ }^{286} \mathrm{Haljina}$ je napravljena od grubog materijala raše ili nekog obojenog platna (spominje se kao tunika). ${ }^{287}$

Navedena vrela ukazuju nam da je zalog kao oblik garantiranja bio vrlo važan u poslovanju. Na temelju zaloga dužnik bi dobio zajam, služio je za trgovinu, a često je korišten i kao sredstvo za dobivanje potrošačkog kredita.

\section{Prokuratori}

Prokuratori su opunomoćeni trgovčevi zastupnici. Njihov je zadatak obično bio da u ime trgovaca podignu kredit, podmire dug, vode parnicu na sudu, jamče da će se zajam vratiti na vrijeme i sklapaju druge različite ugovore: mogli su, primjerice, vršiti funkciju jamca dužnika. Imali su važnu ulogu u komercijalnim i kreditnim poslovima grada. ${ }^{288}$

Dokumenti koji se odnose na Ulcinjane ponegdje sadrže dodatne informacije o izvršenom vraćanju zaduženja i prokuratorima koji preuzimaju daljnju doplatu. Udovica Bjelče (oko 1330. - oko 1376/87.), starateljica zaostavštine pokojnog Mata Bazilijeva Basilija, dostavlja 14. listopada 1367. sudu ispravu (od 25. veljače 1365.) u kojoj se navodi da Džive Marinelli iz Ulcinja duguje 38 dukata njezinu pokojnom suprugu. ${ }^{289}$ Marin Tanov iz Ulcinja dobio je dozvolu da vrati dug u ime Bjelče i njezina sina Bahoja Matova. Prokurator Marin istog je dana bio opunomoćenik Lukine udovice Katalene koja je potraživala dug od udovice Bjelče i sestre njezina pokojnog supruga - Katarine (oko 1315. 1366.). Konstatirano je da je dug prema Kataleni i njezinim sinovima namiren. Naznačeno je da se po tom temelju ne smije potraživati novac ni bilo što drugo (pod prijetnjom kazne od tisuću dukata). ${ }^{290}$ Kao Ulcinjanin, Marin je dobro poznavao trgovačke obitelji iz tog grada. Udovica Draža 14. listopada izjavila je: od njezine ostavštine (nakon smrti) treba isplatiti 500 perpera njezinoj

285 Konstantin JirečEK, Spomenici srpski, Spomenik SKA, sv. 11, Beograd, 1892., 36 № 20; Tadija SMIČı klas, Diplomatički zbornik Kraljevine Hrvatske, Dalmacije i Slavonije, sv. XIV., Zagreb, 1916., 146, № 95; Ljubomir Stojanović, Povelje i pisma I-1, Beograd, 1929., 105, № 105; K. JiReČEK, Romani, 274.

286 Div. Can., sv. 27, f. 226v, (1.6.1389.).

287 D. Dinić-Knežević, Položaj žena, 172.

288 I. VoJe, Kreditna trgovina, 122, $128-130$.

289 Deb. Not., sv. 7, f. 111v, (14. 10. 1367.); Vidjeti: N. VeKARIĆ, Vlastela grada 7, 57 - 58.

290

Deb. Not., sv. 7, f. 111v, (14. 10. 1367.); Vidjeti: N. VeKARIĆ, Vlastela grada 7, 58. 
sestri Kataleni i kćerima. Marin je bio opunomoćenik i njemu je trebalo dati novac. ${ }^{291}$ Ovaj slučaj završen je 23. rujna 1380 . godine. ${ }^{292}$

Nikola iz Ulcinja u listopadu 1367. istupa kao prokurator Veproja s Lopuda. ${ }^{293}$ Kao prokurator zabilježen je krojač Domanja Duornich. U ime ulcinjskih trgovaca dizao je zajam i davao jamstva. Domonja se spominje 11. rujna 1368. kao prokurator Prvoša Sevasta iz Ulcinja. Izjava je napisana rukom svećenika Prode, ulcinjskog notara. Zaduženje je bilo kod Pavla Nikova Barabe i Pavla Georgija (oko 1347. - oko 1374.), a iznosilo je tisuću dukata (otplativih do mjesec dana od prvog predstojećeg putovanja). ${ }^{294}$ Ako dugovan iznos ne bi bio isplaćen u navedenom roku, dubrovačke gradske vlasti mogle su izdati nalog da se Sevasto uhvati i zatvori, ako se nalazi u Ulcinju, Baru, Skadru, Dubrovniku i Kotoru (na ovom području bio je trgovački aktivan). Trebao je biti zadržan u zatvoru do potpune isplate duga. Domanja nije naplatio spomenuti kreditni iznos. Iz isprava od 20. lipnja 1381. saznajemo da je dužnik Prvoš umro pa je sada prokurator bio dužan otplatiti dug. ${ }^{295}$ Domanja je blisko surađivao sa spomenutim kreditorima. Međutim, dug nije bio otplaćen ni 1381. Sredinom srpnja iste godine odobreno je tutoru nasljednika Matu Vidovu Georgiju da pošalje u Ulcinj dvije povelje, radi naplate dugova. ${ }^{296} \mathrm{Ne}$ znamo kako je ovaj slučaj okončan jer nismo našli podatke u vrelima. Sedam godina kasnije (9. 11. 1388.) braća Matija i Marin, sinovi pokojnog Ivana Grada (građanina Dubrovnika), dali su prokuratoru Iliji Marinovu iz Ulcinja punomoć da naplati dug od svog sugrađanina Radina Rusnića. ${ }^{297}$

Iz navedenih primjera vidimo da su prokuratori imali važnu ulogu oko preuzimanja daljnje isplate zaostalog duga. Spomenuti prokuratori bili su trgovci podrijetlom iz Ulcinja, surađivali su s kreditorima i poznavali dužnike. Zbog toga je postojala „vjera” u ove prokuratore da će dug biti vraćen.

291 Deb. Not., sv. 7, f. 111v, (14. 10. 1367.).

292 Deb. Not., sv. 9, f. 29v, (23. 9. 1380.).

293 D. Dinić-Knežević, Migracije stanovništva, 135.

294 Ego quidem Domagna de Duornich, procurator legittimus ad infrascripta Pervossii de Sevasto de Dulcinio... me obligo dare et solvere Paulo de Baraba et Paulo de Georgio ducatos auri mille... Deb. Not., sv. 7, f. 157v, (11. 9. 1368.). Nismo uspjeli naći podatak kojoj grani roda Georgio pripada Pavle. I. Manken smatra da je bio vanbračni sin i da je zbog toga pripadao pučanskom sloju stanovništva. Vidjeti: I. Manken, Dubrovački patricijat I, 207 - 208; I. MANken, Dubrovački patricijat II, 33.

295 Deb. Not., sv. 9, f. 66v, (20.6.1381.).

296 Ludovicus de Thallóczy, Constantinus Jireček, Emilianus de Sufflay, Acta et diplomata res Albaniae mediae aetatis illustrantia II (annos 1344 - 1406 continents), Vindobonae (Beč), 1918., 89, br. 373 .

${ }^{297}$ Div. Not., sv. 10, f. 29v, (9. 11. 1388.). Nismo uspjeli pronaći podatke o Ivanu Gradi, vjerojatno je bio pučanskog podrijetla. Vidjeti: I. MANKEN, Dubrovački patricijat II, 49; N. VE KARIĆ, Vlastela grada $7,338-339,355$. 


\section{ROKOVI VRAĆANJA KREDITA}

Jedna od najvažnijih komponenti kreditne isprave je rok otplate zajma. Rokovi su se u dubrovačkoj kreditnoj ispravi označavali na najrazličitije načine. ${ }^{298}$ Otplata duga kretala se u rasponu od jednog do šest mjeseci. Od mjesečnih rokova najčešće se određuje termin plaćanja od 3 mjeseca (od prvog putovanja). Dubrovčani su smatrali da je ovo dovoljan rok da trgovac ode u Zetu da bi prodao robu i vrati se natrag. Kod termina zaduživanja kolegancije rokovi su duži, navodi se pola godine. Kao termin plaćanja često se označavao praznik. Vitko Bube zadužio se 30. siječnja 1368. u iznosu od 12 dukata do sljedećeg Uskrsa. ${ }^{299}$ Kredite su dužnici mogli otplaćivati u ratama. Marin Dessi zadužio se u iznosu od 73 dukata 1380., obvezao se da će svake godine služiti i plaćati po 15 dukata, sve dok dug ne bude potpuno podmiren. Ako neke godine ne uplati dogovorenu ratu, vjerovnik ima pravo zatražiti sav ostatak duga. ${ }^{300}$ Ovaj ugovor je zanimljiv jer pokazuje da se kredit mogao vratiti i nekim fizičkim radom (službom).

U slučaju nevraćanja duga postojala je pravna institucija aptagi koja se primjenjivala u potraživanju kredita. ${ }^{301}$ Kreditor je bio iznimno dobro zaštićen jer je isprava zastarijevala tek nakon 30 godina. Bilo je čak moguće ovaj rok produžiti na još 30 godina ako vjerovnik podnese zadužnicu knezu i trojici sudaca. Oni su zadužnicu registrirali u posebnu knjigu (quaternus comunis) i na taj način produžavali punovažnost. ${ }^{302}$

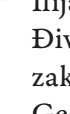
Georgiju vidjeti: N. VeKARIć, Vlastela grada 2, 254; N. VekARIć, Vlastela grada 7, 298. Aptagi su se koristili u imovinsko-pravnim sporovima čiji je predmet bilo neko potraživanje. Određuje se rok u kojem dužnik mora platiti dug ili se nagoditi s vjerovnikom. Nagodba se sastojala od produženja roka. Ako se u određenom roku dužnik ne nagodi s vjerovnikom i ne plati dug, vjerovnik je bio obvezan da na teret dužnika isplaćuje knezu taksu u visini $10 \%$ glavnine duga i pristupa se izvršenju. Vjerovnik je plaćanjem visoke takse knezu na teret dužnika dobio vrlo efikasnu zaštitu svojih interesa. Za dužnika je plaćanje takse predstavljalo poskupljenje troškova spora i veliki teret, ali je također imao i određenih prednosti u odnosu na redoviti parnični postupak. Vjerovnik koji nije bio siguran u financijsku sposobnost svoga dužnika i nije bio osiguran zalogom birao je postupak po aptagi. O tome više: Statut grada Dubrovnika, 216 - 221; Jelena DANILović, O pravnoj prirodi i razvoju ustanove "Aptagi“ dubrovačkog prava, Istoriski časopis, sv. 12 - 13, Beograd, 1961. 1962., 31 - 90; I. VoJe, Poslovna uspešnost, 75 - 76; Viktor PALIĆ, Naplata sudskih pristojba u srednjovjekovnom Dubrovniku, Povijesni zbornik, sv. 1, br. 1 - 2, Zagreb, 2007., 44 - 45.

302

I. VoJe, Kreditna trgovina, 77. 


\section{KAMATE}

Ugovorena kazna, u slučaju da se zajam ne vrati u predviđenom roku, često se primjenjivala. Obično se navodi kao dodatna klauzula u ugovoru. Novčana potraživanja za koju je sastavljena notarska isprava u vidu zadužnice bila je osigurana ugovorenom zateznom kaznom u iznosu od $20 \% .{ }^{303}$ U Kotoru je zatezna kamata također iznosila $20 \%{ }^{304} \mathrm{U}$ Veneciji je osim predviđene zatezne kamate od $20 \%$ uziman još i duplum. ${ }^{305}$ Uzimanje kredita uz kamatu bilo je zabranjeno dubrovačkim statutarnim pravom. Također, Crkva se suprotstavljala pozajmljivanju novca uz naknadnu kamatu, vjerujući da je takav prihod nelegalan i pljačka bližnjega u nevolji. ${ }^{306}$ Međutim, u stvarnosti su postojali i primjeri suprotne prakse. ${ }^{307} \mathrm{U}$ ugovore o kreditiranju kamata se nije unosila. Trgovac koji je davao dužniku robu na kredit uračunao bi svoju zaradu u ukupan iznos u nekoj moneti. U Dubrovniku je bilo dozvoljeno uzimanje zatezne kamate $\mathrm{u}$ iznosu od 15 posto. ${ }^{308}$

Osim ugovorene kazne u novcu predviđene su i dodatne kazne. U slučaju da obveza ne bude ispunjena na ugovoren način ili na vrijeme, vjerovnik može bez posredovanja suda poslati dužnika u zatvor. ${ }^{309}$ Nismo našli primjere zajma Ulcinjana samo „na vjeru“, produživanje roka otplate bez kamata i sl., što je bilo u suprotnosti s navedenom praksom provođenja teških kaznenih mjera $u$ slučaju neplaćanja.

\section{ZAKLJUČAK}

Ulcinj i Dubrovnik imaju sličan geografski položaj na Jadranu i razmjerno su bliski, što upućuje na međusobnu trgovinu. Njihove međusobne veze jačaju tijekom XIV. stoljeća, kad Dubrovnik poslije Zadarskog mira i Višegradskog ugovora ulazi

303 I. VoJe, Kreditna trgovina, 175 - 177.

304 Istorija Crne Gore II/1, Titograd, 1970., 39.

305 I. VoJe, Kreditna trgovina, 177.

306 Statut grada Dubrovnika, 431 - 432; I. VoJE, Kreditna trgovina, 176 - 177.

307 O tome vidjeti: John A. F. Thоmson, The Western Church in the Middle Ages, London, 1998.; Robert B. Ekelund, JR., Robert F. HÉBert, Robert D. Tollison, The Political Economy of the Medieval Church, Oxford Handbook of the Economic of Religion (ed. Rachel M. McCleary), Oxford, 2011.

308 I. VoJe, Kreditna trgovina, 169 - 175.

309 Ego quidem Marinus, fiiius Dessi de Dulcinio, confiteor, quod super me et super omnia bona mea usque ad tres menses... Et si ultra dictum terminum etc...et possit me contravenire et capi et incarcerari facere in pecunia et rebus, Dulcinii, Cathari, Antibari, Ragusii et ubicunque locorum per... suam solucionem. Deb. Not., sv. 7, f. 179v, (17. 3. 1369.). 
u veću zajednicu, Ugarsko-hrvatsko Kraljevstvo, i samim time postaje zanimljiviji poslovnim partnerima iz drugih zemalja jer se otvara jedno novo i veliko tržište. Ulcinj istovremeno nakon dinastičkih borbi, eliminacije Dušanovih nasljednika i pritiska albanskih velikaša ulazi u stabilan period rasta i napretka u sklopu Zete Balšića, koji ionako razvijaju veze s Dubrovnikom. Ulcinjsko-dubrovačke trgovačke veze realiziraju se prvenstveno kroz robno-novčanu razmjenu, pri čemu sve veći značaj dobiva kreditna trgovina, zbog širenja poslova i potrebe za sve većim novčanim izdatcima. Dok Dubrovčani vide Ulcinj samo u sklopu šire slike svojih veza sa Zetom, Ulcinjani kupuju nekretnine u Dubrovniku i okolici i teže stjecanju dubrovačkog građanstva, $s$ ciljem dobivanja dodatnih povlastica $u$ trgovini. Presjek odnosa dviju jadranskih komuna na području trgovine postupno je prešao dug put od robno-novčane razmjene i nabave sirovina, preko kreditne trgovine do političkog uspjeha pojedinaca koji su diplomatski djelovali u Ulcinju (Dubrovčani) ili stjecali drugo građanstvo (Ulcinjani). Najvažnije obitelji i osobe čije nam karijere govore o tom razvitku su Clime, Bube, Sevasto, Dabro, don Marin Ivanov, Slavko Marinov Slavi, Marin Dessi, Marin Nikolin, Stjepan Marinov, Marinče Karolli, Marin Dimitrijev, Brajko Milošević i Marko Tano te Dubrovčani Vido Matov Georgio, Luka Mihov Bona, Marin Vidov Benessa, Mato Vidov Georgio, Junije Matijašev Grade, Pavle Nikov Baraba, Nikola Đurov Caboga, Vido Šimunov Benessa, Petar Marinov Bocinolo, Pavao Vidov Palmota, Nikola Džorin Palmota i Mihoč Šimunov Resti. Udruživanje Ulcinjana u gradu i poslovna suradnja s dubrovačkom vlastelom odvijala se preko rodbinskih, prijateljskih i poznaničkih veza. Osim poznatijih trgovačkih obitelji i trgovaca, nabrojani su trgovci koji su jednom ili dva puta uzeli kredit.

Ulcinjski trgovci u Dubrovniku trgujući navedenim artiklima (sol, žito, vosak, vino, lađe, tkanine) i baveći se kreditnom trgovinom učinili su važan korak u sređivanju svog statusa u Dubrovniku. Ulcinjani Marin Nikolin, don Marin Ivanov i Stjepan Marinov kroz trgovinu su stekli povjerenje uglednih pojedinaca i gradskih vlasti pa su dobili pravo dubrovačkog građanstva. Poslujući s Dubrovčanima, ulažući u dubrovačku imovinu i, naposljetku, kupujući nekretnine na teritoriju dubrovačke komune/buduće republike, ulcinjski trgovci stječu bolji politički i društveni status u Dubrovniku kao stalni naseljenici.

$\mathrm{Na}$ osnovi analize ugovora utvrdili smo da se u kreditnim transakcijama puno više poslovalo robom, a manje novcem. Na temelju Debita ne može se sagledati cjelokupan kreditni promet jer za pojedine godine knjige zaduženja nisu sačuvane u cjelini (1370. - 1378., 1382. - 1389. i 1396. - 1400.). Najviše su se stanovnici iz Ulcinja kreditno zadužili 1367., na iznos od oko 4.401 dukata. Temeljne karakteristike Ulcinjana tijekom zaduživanja u gradu možemo 
sagledati kroz tri različita razdoblja. Prvo razdoblje od 1352. do 1369. predstavlja aktivno zaduživanje i najveći broj zajmoprimaca, uglavnom na iznose od 100 do 700 dukata. U drugom razdoblju od 1378. do 1382. kreditiranje je bilo slabije. Zabilježeno je samo osam kredita, a zbroj zaduženja se kreće od 25 do 196 dukata. Treće razdoblje od 1389. do 1396. prikazuje pojačano zaduživanje nekoliko istaknutih trgovaca na iznose od 17 do 252 dukata.

Ulcinjski trgovci se udružuju, među sobom ili s Dubrovčanima, i sklapaju trgovačka društva zbog stvaranja profita i uvećanja kapitala. Najčešći oblik udruživanja u ovom razdoblju bila je kolegancija. Trgovci koji su dolazili u grad prvi puta ili nisu bili dovoljno poznati dobivali su kredit na temelju garancija jamca, davanja zaloga i jamstva prokuratora. Rok otplate duga bio je različit, kretao se od jednog do šest mjeseci. Od mjesečnih rokova najčešće se određuje termin plaćanja od 3 mjeseca. Ugovorena kazna u slučaju da se zajam ne vrati u predviđenom roku često je primjenjivana, ona se nalazila kao dodatna klauzula u ugovoru i iznosila je $20 \%$.

Gospodarski razvoj Dubrovnika u drugoj polovici XIV. stoljeća privukao je velik broj stanovnika iz ulcinjske komune. Ekonomske potrebe stanovnika Ulcinja utjecale su na to da uzimaju kredit u Gradu. Dubrovačko davanje kredita bilo je orijentirano vlastitoj dobiti (materijalnoj koristi) i prosperitetu u budućnosti. Ulcinjane je također privlačila dobit i napredak. Odnosi povjerenja razvijali su se vremenom, mnogogodišnjim poslovanjem između istih osoba. $\mathrm{Na}$ taj način stvarala se stabilnost trgovačkih odnosa između Ulcinja i Dubrovnika.

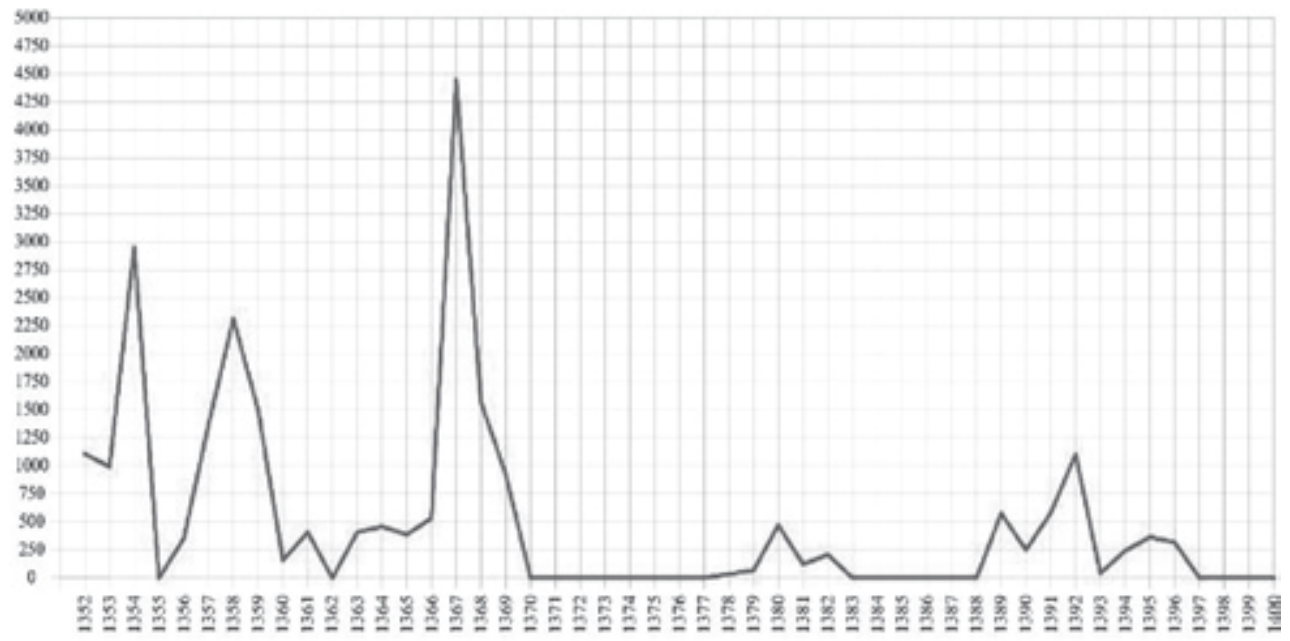

Grafikon 1. Zaduživanja Ulcinjana u Dubrovniku 
Marijan PREMOVIĆ

\section{RESIDENTS OF ULCINJ IN CREDIT TRADE OF DUBROVNIK IN THE SECOND HALF OF 14th CENTURY}

\section{SUMMARY}

This paper provides an overview of the credit trade of residents of Ulcinj in Dubrovnik, in the second half of the 14th century. The research is based on an analysis of Debita notariae records from the State Archives in Dubrovnik. The files from Volumes No. 3 to No. 12, covering the period from 1352 to 1396 were used. To obtain a complete view of activities of Ulcinj traders, we consulted the series: Diversa Cancellariae (XVII-XXXIII) and Diversa Notariae(III-XI). The research of all three sets gave a complete view of the activities of Ulcinj entrepreneurs in the town. The paper is divided into twelve chapters: introduction; political developments in the South Adriatic and their effect on the credit trade; the impact of health conditions; credits; major merchant families; less known Ulcinj traders; merchant societies; trade goods; credit guarantees (guarantors, pledge, procurators); repayment deadlines; interest rates and conclusion.

The economic development of Dubrovnik in the second half of the 14th century attracted a large number of merchants from the Ulcinj Commune. Back then, like today, merchants who did not have their own money were forced to take loans. To get the merchandise, they needed the money that they regularly borrowed in the town for a specified period. Loan contracts had an almost uniform recording format. A usual credit form included mostly the date, names of the debtors, with a special note about their Ulcinj residence, the creditors, the amount of the loan, the repayment period and the measures to secure repayment of the loan. Ulcinj merchants traded with the following articles: salt, grain, wax, wine, boats and fabrics. Development of merchants throughout the years can be observed best based on the total annual amount of loans taken from Dubrovnik merchants. The highest indebtedness of Ulcinj residents was in 1367 to the amount of around 4,401 ducats. In most cases, business in credit transactions was done in goods and less in money.

Due to a more significant number of credits taken, we have succeeded in presenting the dominant merchant families of Ulcinj (Clime, Bube, Sevasto, Dabro) and merchants (don Marin Ivanov, Slavko Marin Slavi, Marin Dessi, Marin Nikolin, Stjepan Marinov, Marinče Karolli, Marin Dimitrijev, Brajko Milošević and Marco Tano). They all got individual business overviews they deserve. The documents record merchants who took loans once or twice. They 
were not successful traders since they do not appear in the sources again. Ulcinj residents made credit deals most frequently with the noble families of Dubrovnik such as Bona, Mençe, Goçe, Basilio, Benessa, Palmota, Baraba, Bocinolo, Resti etc.

Their association in the town and business cooperation with the Dubrovnik nobility were on the lines of relatives, friends and acquaintances. The fundamental characteristics of Ulcinj residents during the loan taking in the town can be presented in three distinct periods. The first period from 1352 to 1369 was the period of active loan taking and the highest number of loan takers, usually to amounts ranging from 100 to 700 ducats. In the second period from 1378 to 1382 , the credit taking intensity was lower. Only eight loans were made, and the sum of loans ranged from 25 to 196 ducats. The third period from 1389 to 1396 was the period of more intensive loan taking by several prominent merchants to amounts ranging from 17 to 252 ducats.

Their association in the city and business cooperation with the Dubrovnik nobility was along the lines of relatives, friends and acquaintances. The essential characteristics of Ulcinj residents when borrowing in the town can be followed through three different periods. The first period from 1352 to 1369 represents active borrowing and the most significant number of borrowers, mainly for the amounts from 100 to 700 ducats. In the second period from 1378 to 1382 , borrowing subsided. Only eight credits were recorded, and the total of the credits ranged from 25 to 196 ducats. The third period from 1389 to 1396 shows an increase in borrowing by several prominent merchants totalling 17 to 252 ducats.

Merchants started to merge and form associations to generate a profit and increase the capital. The most common form of association was that the wealthier merchant most often invested cash, while another member of the company did business and invested his work. Earnings or losses were divided in half. Traders who came to the city for the first time or were not well known were given credit based on guarantor guarantees, pledges and procurator guarantees. The maturity of the debt varied, ranging from one to six months. Of the monthly deadlines, the payment term of three months was most often determined. The citizens of Dubrovnik believed that this was sufficient time for the merchant to go to Zeta to sell the goods and return. The agreed penalty, if the loan was not repaid within the stipulated time frame, was often applied and it was included as an additional clause in the contract and amounted to $20 \%$.

The economic development of Dubrovnik in the second half of the 14th century attracted a large number of residents from the Ulcinj Commune. The financial needs of citizens of Ulcinj made them rely on the town, which is why 
they maintained intensive economic communication and thus contributed to the development of the Dubrovnik Commune. On the other hand, the presence of St Vlaho's Town in the economic prosperity of the Ulcinj Commune was of extraordinary significance.

Keywords: Ulcinj residents, Dubrovnik, credit trade, trade companies, 14th century. 